ENCUESTA 



\section{ENCUESTA SOBRE LA INDEPENDENCIA DEL PODER JUDICIAL}

\section{PRESENTACIÓN}

Nuestra revista, que tempranamente dedicó un monográfico a El poder judicial (n. ${ }^{\circ} 8 / 9,2001$ ), vuelve con esta encuesta a recabar la opinión de constitucionalistas de reconocido prestigio sobre la garantía constitucional de la independencia de jueces y magistrados. Este es un principio que, a pesar de su notoria importancia, no se garantizó suficientemente en el primer constitucionalismo europeo.

La azarosa historia constitucional española gozó de un punto de partida gaditano impregnado de especial preocupación por asegurar la independencia en el ejercicio de la función jurisdiccional, que, como es bien sabido, se apuntó ya en el Decreto de 24 de septiembre de 1810, mientras en el Discurso Preliminar de la Constitución doceañista se consideró que «dos grandes escollos hacen peligrar la administración de justicia, que no es posible evitar del todo mientras las luces no se difundan...», a la par se asentaba una idea fuerza: «en el momento en que ambas autoridades (legislativa y ejecutiva) o alguna de ellas reasumiese la autoridad judicial, desaparecería para siempre no sólo la libertad política y civil, sino hasta aquella sombra de seguridad personal que no pueden menos de establecer los mismos tiranos si quieren conservarse en sus Estados». Pero nuestro constitucionalismo decimonónico, como en general el europeo, trató la independencia de la función jurisdiccional sin dedicar la debida atención a garantizar la independencia del juez que ejerce esa potestad.

Nuestra Constitución de 1978 se plantea la independencia del poder judicial con más ambición y con soluciones en unos casos acertadas y en otros - particularmente el de la composición del Consejo General del Poder Judicial— quizá mejorables. El ansia noble de nuestro pueblo en pro de que se haga justicia en todo caso, cualquiera que sea quien infrinja la ley, no solo constituye un dato a tener en cuenta por quienes están al frente de la vida comunitaria del país, sino que debe ser acreedor de un esfuerzo por parte del profesorado de nuestra rama científica, que posiblemente no hayamos dedicado a tan delicada cuestión toda la atención que requiere.

La independencia de jueces y magistrados es cuestión de particular complejidad, pues al menos, como todos sabemos, tiene un doble sentido: la indepen- 
dencia funcional o imparcialidad en el desempeño de la función jurisdiccional y la independencia orgánica, que blinda la posición del juez (inamovilidad, incompatibilidades, deber de abstención y facultad de recusación...) y justifica la existencia del Consejo General del Poder Judicial. También para garantizar la independencia de los jueces la ley permite a estos que cuando actúan en órganos colegiados puedan emitir votos particulares.

Se trata de una materia poliédrica, que los constitucionalistas hemos dejado casi por entero en las buenas manos de los procesalistas, aunque posiblemente debamos preguntarnos si es factible renunciar a la reflexión sobre la misma pues, en última instancia, de que se resuelva perfectamente dependerá nada menos que nuestro Estado realmente lo sea de Derecho, es decir, que todos los poderes públicos estén sometido al imperio de la ley; o que, expuesto en otros términos, el ejercicio de los poderes del Estado goce de auténtica legitimación democrática, bajo la supervisión de jueces independientes, que cuando actúan no imponen su propia voluntad, sino la voluntad general, es decir, la voluntad de los ciudadanos expresada en la ley. De manera que se nos antoja dudoso que los constitucionalistas podamos dejar a un lado el estudio de la composición y funcionamiento del Consejo General del Poder Judicial o que podamos mirar en otra dirección ante el singular fenómeno de que el nuestro sea el único Estado miembro de la UE en que hay miles de personas aforadas.

Por cuanto antecede, el agradecimiento que expresamos a los eminentes constitucionalistas que contestan en esta ocasión nuestra encuesta está bastante más allá de la debida cortesía. Es una especial gratitud a quienes mantienen la cabeza atenta hacia facetas problemáticas de uno de los grandes pilares que mantienen en pie nuestro Estado de Derecho y han querido honrarnos con unas jugosas respuestas, cuya lectura agradará a todos nuestros buenos lectores.

\section{CUESTIONES}

1. ¿Qué correlación considera usted que debe establecerse entre la independencia del poder judicial y la calidad de un Estado de Derecho de nuestro tiempo? ¿En España hoy le parece óptimo el nivel de independencia respecto del poder político?

2. ¿Qué nos quiere decir sobre el sistema de composición y de funcionamiento de nuestro Consejo General del Poder Judicial desde la óptica de su despolitización? ¿Piensa que la LO del Poder Judicial 6/1985 constituyó un avance o un retroceso en cuanto a la elección de los componentes del Consejo? ¿Sugeriría algunos criterios para su posible reforma?

3. ¿Considera que podría llegar a preocupar la neutralidad del CGPJ en materia de ascensos a juzgados sensibles como los de Instrucción de la Audiencia Nacional o a salas de lo penal importantes como la de los TSJ de las CCAA o del Tribunal Supremo?

4. ¿Qué valoración le merece el que España sea con mucho el Estado miembro de la Unión Europa con mayor número de políticos aforados? ¿El que los responsables públicos de las Comunidades Autónomas estén aforados ante el TSJ de la propia Comunidad, puede 
motivar el que aquellos busquen incrementar las competencias autonómicas respecto de los juzgados y tribunales sitos en su territorio? ¿Sugeriría usted la supresión total o parcial de los aforamientos?

5. Como sabemos el artículo 118 CE dispone que "Es obligado cumplir las sentencias», pero a la vez el art. 62, i) reconoce "el derecho de gracia con arreglo a la ley», a lo que se añade el que se ha mantenido vigente la Ley de 18 de junio de 1870, por lo demás, modificada por la Ley 1/1988 que eliminó la motivación preceptiva en los indultos parciales. ¿Qué valoración le merece esta legislación sobre el indulto y el uso que de la misma puede hacer cada Gobierno? ¿Nos propondría alguna reforma normativa?

6. ¿En el terreno de las prácticas y de los usos de nuestro Estado de Derecho podemos entender que el Ministerio Fiscal tiene suficientemente asegurado el ejercer sus funciones conforme a los principios consagrados en el art. 124 CE de «legalidad e imparcialidad»?

7. ¿Desea usted hacer alguna otra sugerencia sobre cómo asegurar en nuestro Estado de Derecho la vigencia práctica de la independencia de los órganos de nuestra Administración de Justicia?

\section{ENCUESTADOS}

RAFAEL BUSTOS GISBERT, Catedrático de Derecho Constitucional (A), Universidad de Salamanca.

JUAN FERNANDO LÓPEZ AGUILAR, Catedrático de Derecho Constitucional, Universidad de Las Palmas de Gran Canaria.

PABLO LUCAS MURILLO DE LA CUEVA, Catedrático de Derecho Constitucional. Magistrado del Tribunal Supremo.

ANGEL RODRÍGUEZ-DÍAZ VERGARA, Catedrático de Derecho Constitucional, Universidad de Málaga.

\section{RESPUESTAS}

1. ¿Qué correlación considera usted que debe establecerse entre la independencia del poder judicial y la calidad de un Estado de Derecho de nuestro tiempo? ¿En España hoy le parece óptimo el nivel de independencia respecto del poder politico?

\section{RAFAEL BUSTOS GISBERT}

La independencia judicial es una de las claves de bóveda del Estado de Derecho desde su creación. Su importancia es difícilmente exagerable. Pero posiblemente tengamos ahora otras dimensiones como consecuencia de la aparición de nuevos Tribunales más allá de los Estados cuya independencia ha de garantizarse sobre la base de nuevos ejes. El tradicional respecto a los poderes de las organiza- 
ciones internacionales a las que pertenecen; el vertical respecto al Estado miembro sujeto a sus decisiones y que de alguna manera «suministra» los jueces que los componen; y el social que supone la necesidad de asegurar su independencia frente a grandes grupos o empresas transnacionales cuyo funcionamiento no es transparente pero cuyos negocios dependen de manera muy directa de las decisiones de tales órganos. Algo parecido puede decirse respecto a la creación de redes de arbitraje internacional...

En lo atinente a la concepción más tradicional de la independencia judicial vinculada al Estado de Derecho no puede comenzarse esta encuesta sin destacar algunos fenómenos preocupantes en países de nuestro entorno geográfico y cultural (Europa y América). Algunos de los nuevos movimientos que están transformando el panorama político en estos países muestran un desprecio, en algún caso absoluto, hacia la independencia judicial en la medida en que consideran al juez un contrapeso que frena sus ansias de transformación de la sociedad. Este es, a mi juicio, el mayor peligro para la independencia judicial en la actualidad. Centrándonos en nuestro entorno más cercano la regresión sufrida por la independencia judicial en Estados miembros de la UE no puede ni debe ser minusvalorada. No es ocioso recordar al comienzo de esta encuesta el ataque a la independencia Judicial sufrido por el poder judicial en Hungría y a duras penas contenido por el Tribunal de Justicia de la Unión Europea a instancias de la Comisión (anulando la jubilación anticipada por reforma legal de los jueces menores de 62 años para librarse de los miembros de las más altas magistraturas del Estado) o del propio TEDH (estableciendo la obligatoriedad de la revisabilidad judicial y el respeto al proceso debido en toda decisión legal e incluso constitucional que suponga la exclusión de jueces del ejercicio de sus cargos en Baka c. Hungría siguiendo la triste línea iniciada por la Corte Interamericana en reverón Trujillo c. Venezuela —bajo el gobierno de Hugo Chavez-, Tribunal Constitucional c. Perú —-bajo Fujimori- o Tribunal Constitucional c. Ecuador —bajo Correa-). Del mismo modo no ha de mirarse para otro lado si contemplamos la regresión en Polonia, el durísimo informe de la Comisión Venice del Consejo de Europa sobre la materia o el inicio, por primera vez en la historia de la Unión Europea, del procedimiento de sanción a un Estado miembro por violación de los principios esenciales del Estado de Derecho previsto en el art. 7 TUE, precisamente por violación de la independencia judicial.

En este contexto creo que no resulta exagerable advertir que la independencia judicial es un elemento básico del Estado de Derecho que constituye una de las líneas rojas que ningún grupo político significativo ha de poner en riesgo o cuestionar en la más mínima medida.

Entrando en concreto en el tema planteado en la pregunta respecto a la independencia judicial debemos diferenciar la independencia interna y la externa. Respecto a la primera (ausencia de presiones desde dentro del poder judicial, y en especial desde las presidencias de tribunales colegiados o de tribunales superiores hacia los inferiores) no creo que haya grandes problemas aunque algunos elemen- 
tos de la crisis económica en el poder judicial está dando lugar a prácticas que pueden poner en riesgo esta independencia como es la generalización de jueces de adscripción territorial como consecuencia de la ausencia de fondos para crear nuevos juzgados. Estos jueces son adscritos por los Tribunales Superiores de Justicia en función de las necesidades por lo que pueden alterarse los principios tradicionales regidores de la inamovilidad en los puestos. Otro tanto ocurre con los jueces de refuerzo, especialmente en altos tribunales, en cuya designación, dado su carácter temporal, no rigen las mismas normas que en el resto de concursos internos del poder judicial lo que puede dar lugar a situaciones indeseables desde el punto de vista de la defensa de la independencia interna.

También puede apreciarse en la práctica judicial española, en lo referente a independencia judicial, lo que un compañero ha denominado «un cierto espíritu gregario» destacando la tendencia, especialmente en la primera instancia, a cambiar u orientar el propio criterio en función de la posición adoptada por la instancia superior (normalmente la Audiencia), donde lo relevante en la decisión judicial no es la forma en que el juez entiende que debe aplicarse el Derecho al caso concreto. Al contrario, en este tipo de situaciones lo único que importaría sería las probabilidades de que la propia decisión sea revocada o no por la sala superior.

Respecto a la llamada independencia externa (ausencia de presiones desde fuera del poder judicial) creo hay algún problema, no excesivamente grave todavía pero al que debería hacerse frente cuanto antes para evitar que se pudiera convertir en irremediable (véase infra). Quizás en este punto también sería destacable algún peligro vinculado a la infradotación de medios de los juzgados y tribunales que ha dificultado enormemente la labor de jueces y tribunales. No puede entenderse como una agresión a la independencia, pero lo cierto es que es a las administraciones (estatal o autonómica según los casos y según se hayan o no asumidos competencias en esta materia) a las que corresponde dotar de tales medios suficientes y, en ocasiones no parece que exista un interés político real en que los juzgados y tribunales dispongan de los suficientes medios.

Finalmente habría que hacer frente a dos tipos de problemas relevantes. Se refiere el primero al papel de las asociaciones judiciales y atañe el segundo a la aparición de grupos o grupúsculos en el seno de la carrera.

Respecto al asociacionismo judicial sin duda está suficientemente asentado y cumple unas funciones relevantes en el conjunto del poder judicial. Sin embargo, el papel desempeñado por las asociaciones es jurídicamente difuso si bien su importancia tanto en el seno de la carrera como en la relación con otros poderes (incluida la opinión pública) es evidente. Sería bueno que tal papel se aclarara y se evitaran situaciones en las que resulte demasiado sencillo establecer unas conexiones (por otra parte frecuentemente injustas, pero en ocasiones reales) entre asociación y partido político concreto. En este punto la creación de convenciones o meras prácticas que aseguraran una exquisita separación entre la vida asociativa y la promoción a presidencias de Audiencia, de TSJ o de Tribunal Supremo o incluso a las vocalías del CGPJ sería enormemente conveniente para mantener las 
funciones importantes que las asociaciones desempeñan y, al mismo tiempo, alejarlas de una politización que en nada las beneficia.

En segundo término, y ya separándonos de las asociaciones, es de destacar la aparición de fenómenos que quizás tengan más que ver con la imparcialidad objetiva (que resulta difícilmente separable a menudo de la independencia) y que se vinculan a la aparición de una cierta «promiscuidad grupal» entre personas vinculadas a la carrera judicial que a través sistemas de apoyo mutuo, que se parecen demasiado a formas de clientelismo, generan inquietud cuando no escándalo en la opinión pública. Me refiero a ciertos grupos o clanes creados a partir de la coincidencia en determinados destinos o a una misma procedencia geográfica o a una simple presencia continuada en algunas decisiones relevantes o, en fin, la compartición de un mismo grupo de preparadores desde la época previa al ingreso en la carrera, que parecen ejercer apoyos muy considerables en favor de las personas más cercanas. No es algo desde luego infrecuente en nuestro país en otros ámbitos (la Universidad sería sin duda uno de esos lugares donde se crean estas familias o escuelas de dudoso comportamiento en muchas ocasiones) pero sí resulta especialmente preocupante cuando se producen en el mundo judicial puesto que la función desarrollada es particularmente delicada y porque, al fin y al cabo, cada juez personifica en sí mismo a todo el poder judicial.

\section{JUAN FERNANDO LÓPEZ AGUILAR}

Esa correlación se encuentra efectivamente establecida desde los orígenes mismos del pensamiento demoliberal sobre el que se cimienta el edificio histórico del constitucionalismo. Desde los prolegómenos de la doctrina de la separación de poderes, con sus referencias clásicas en Locke y en Montesquieu, la premisa de un poder judicial «independiente» de los demás poderes constituidos es un requisito clásico del Estado de Derecho, singularmente en la acepción constitucional asumida en Europa, como marco comparado, desde la II Posguerra.

Tanto en la acepción anglosajona del constitucionalismo (Common Law) como en la continental, la configuración institucional de un Poder Judicial integrado por una pluralidad de órganos (y magistrados) revestidos de un cuadro de garantías de independencia para el ejercicio de su autoridad en la resolución de controversias (inamovilidad, retribuciones aseguradas frente a la arbitrariedad y cualquier forma de injerencia proveniente del poder político, y sujeción exclusiva a su propio estatuto constitucional y legal) resulta de la decantación de un proceso histórico con líneas comunes de interés para el comparatista.

Más reciente en el tiempo es, en cambio, la teoría constitucional que contrapone la acepción «negativa» de la indicada independencia (para afirmar, esencialmente, jueces independientes del poder ejecutivo, en lo que se denomina «reserva de jurisdicción» para los titulares de ese poder del Estado, al margen de cuál sea el sistema de acceso o reclutamiento del servicio a ese poder) frente a una 
acepción positiva (que complementa la anterior con «exclusiva dependencia del imperio de la ley» de jueces y magistrados en su función jurisdiccional consignada en el art. 117.1 CE).

Y aún más reciente todavía lo es la problemática de la contraposición de la «independencia» del juez como garantía funcional del juez en el acto de «juzgar y hacer ejecutar lo juzgado» respecto de las amenazas (y de la consiguiente carencia de protección efectiva y suficiente) de esa misma independencia frente a presiones y/o coacciones provenientes de otras esferas de poder no formalizadas por la Constitución: poderes fácticos, financieros, económicos y mediáticos.

En el específico cuadro comparativo del Derecho continental que opta por el llamado «modelo de juez burocrático» (con una judicatura integrada por un «cuerpo» al que se accede por «examen»u «oposición» competitiva, esquema en que se incluyen Francia, Italia, Bélgica, Portugal, España, entre otros ordenamientos influidos por el modelo francés, con variaciones sociológicas en lo que respecta al estrato de extracción de la composición de la judicatura y a su comportamiento), queda por elaborar, no obstante, la protección de esa independencia frente a los componentes sistémicos de la «carrera» del juez.

En efecto, en un entorno que consagra ese modelo de juez «burocrático/corporativo», en que las resoluciones jurisdiccionales influyen (y alguna vez determinan) el despliegue de las expectativas (legítimas) e intereses (profesionales) de jueces y magistrados, su propia independencia encara importantes desafíos ante la particular ordenación de la «carrera del juez» (compelida a congraciarse o a disgustar lo menos posible a los jerarcas que decidan las promociones y ascensos).

Es éste el caso español, en el que el CGPJ —órgano constitucional (art. 122 CE y 59 LOTC) precisamente diseñado para garantizar la independencia de los miembros del Poder Judicial- ejerce unas competencias (nombramientos, inspección, disciplina, sanciones) ciertamente influyentes en la conducta de los jueces...y en la llevanza de los asuntos de su jurisdicción.

Mi conclusión reafirma la que he puesto por escrito en distintas ocasiones: en el ordenamiento español, la independencia del juez puede entenderse satisfactoriamente asegurada frente al «poder político»: las posibilidades de intervenir en la llevanza concreta de asuntos jurisdiccionales por medio de una injerencia en la esfera privativa del titular (juez/a) o del miembro de órgano colegiado (magistrado/a en tribunal) por parte de quien ostente mandato representativo (concejal/a o diputado/a autonómico o nacional, senador/a, eurodiputado/a...) o responsabilidad en órganos ejecutivos (alcalde/alcaldesa, consejero/a o presidente/a autonómico, ministro/a o presidente/a del Gobierno) tropezará con blindajes y garantías efectivas de protección de la decisión que compete a cada órgano judicial.

Para expresarlo claramente: ningún ministro/a tiene margen alguno de maniobra para injerirse ni influir en asuntos judiciales, puesto que el poder político que reside en el Ejecutivo no tiene ningún instrumento de presión sobre los jueces ni sobre ningún juez. Las garantías efectivas de su inamovilidad, sus retribuciones fijadas por la ley, el cuadro legalmente tasado de responsabilidades (jurídi- 
cas, no políticas: de orden disciplinario, civiles y, en su caso, penales: arts. 405 y ss. Ley Orgánica 6/1985, de 1 de julio, del Poder Judicial), y, en definitiva, su «reserva de jurisdicción», obran en modo que, en España, la ciudadanía puede confiar razonablemente en la independencia del Juez frente al poder político.

A partir de ahí, la variable susceptible de análisis residiría más bien en el escrutinio de las afinidades (ideológicas, políticas, morales o religiosas o de cualquier otro índole) y/o intereses (personales, colectivos, corporativos, económicos) que puedan condicionar la independencia del Juez orientando su conducta y sus resoluciones en un sentido o en otro: ya sea en el momento de la decisión sobre el fondo, ya sea en el curso del procedimiento, acelerando, ralentizando, congelando... «encañonando» selectivamente o «disparando» a discreción en una dirección o en otra...

Huelga recordar, en este punto, que estas consideraciones a las que acabo de referirme conciernen singularmente a un porcentaje muy reducido de actuaciones judiciales, quizá infinitesimal en el contexto general de las cifras y el volumen de la litigiosidad en España (cerca de 7 millones de causas vivas al año): aquéllas en que la independencia pueda verse afectada, siquiera en alguna medida, por algún interés extraprocesal, esto es, no dimanante de las personas encartadas ni de lo que obre en los autos.

\section{PABLO LUCAS MURILLO DE LA CUEVA}

1.1. La relación es esencial: sin jueces independientes no hay Estado de Derecho. No se trata, pues, de una cuestión de calidad sino de existencia. El Estado de Derecho que establece nuestra Constitución descansa en los principios de separación y limitación del poder. Son connaturales al constitucionalismo tal y como lo percibieron los representantes del pueblo francés constituidos en Asamblea Nacional que asociaron solemnemente la idea de Constitución con la separación de poderes y con su razón de ser: la garantía de los derechos, hoy diríamos fundamentales. Y si, desde el artículo 16 de la Declaración de Derechos del Hombre y del Ciudadano de 26 de agosto de 1789, volvemos la vista a algunos de los textos que la precedieron como, por ejemplo, el Ensayo sobre el Gobierno Civil de John Locke, es decir, el segundo de sus Tratados sobre el Gobierno, o al mismo Espíritu de las Leyes de Montesquieu, allí, además de la necesidad de separar los poderes para hacerlos limitados y compatibles con la idea de libertad política, se recoge la noción del juez imparcial.

Mejor dicho, el primero la da por supuesta pues los jueces de los que habla son rectos e imparciales ( $\$ 131$ ), mientras que el segundo, aunque reduzca el cometido de juzgar a pronunciar las palabras de la ley y les considere seres inanimados que no pueden moderar ni su fuerza ni su rigor, se preocupa de decir, en el famoso capítulo VI del Libro XI, dedicado a la Constitución de Inglaterra, que todo estaría perdido si recayeran en las mismas manos el poder de hacer las leyes, 
el de ejecutarlas y el de juzgar. Y, antes de hacer esa advertencia, afirma que no existirá libertad si el poder de juzgar no está separado del poder legislativo y del ejecutivo. Si se une al legislativo, el poder sobre la vida y la libertad de los ciudadanos, dice, sería arbitrario porque el juez sería legislador. Y, si se une al ejecutivo, el juez podría tener la fuerza de un opresor. Los jueces, pues, han de ser independientes y esa independencia sirve para que apliquen sin injerencia ni alteración alguna lo que dice la Ley.

Estas referencias clásicas son plenamente reales y actuales y forman, según decía, parte de la noción de Estado de Derecho, cuyo prestigio como fórmula jurídico-política asociada a los valores de las sociedades civilizadas, permanece incólume y, por eso, es objeto de invocación constante y, a veces, de apropiación interesada en experiencias lejanas de los principios en que descansa, como sucedió en España, a principios de los años sesenta del pasado siglo cuando el régimen de entonces desarrolló, sin éxito, naturalmente, una intensa campaña encaminada a mostrar al mundo el ordenamiento del franquismo como un Estado de Derecho.

1.2. Volviendo sobre el rasgo de la imparcialidad, hay que decir que es connatural a la función de juzgar y, por tanto, a la misma noción y posición de juez. Sin imparcialidad no hay juez y su independencia, corolario del principio de separación de poderes, es el prerrequisito preciso para que sea efectivamente imparcial.

Si proyectamos las ideas anteriores desde la perspectiva concreta de cada juzgador a la institucional que incluye lo que la Constitución llama Poder Judicial, la exigencia de independencia se traslada al conjunto de los jueces y de los tribunales en los que ejercen su función y se afirma frente a los órganos que tienen atribuidas las funciones legislativa y ejecutiva. Es decir, se predica frente a las Cortes Generales y al Gobierno y la Administración que dirige y, si se quiere completar el enfoque, también se predica frente a las asambleas legislativas de las Comunidades Autónomas y sus Consejos de Gobierno y Administraciones respectivas, además, naturalmente, de afirmarse dicha independencia, respecto de las corporaciones locales y de otra naturaleza que existen en nuestro ordenamiento jurídico. Es decir, la exigencia de la independencia judicial se proyecta sobre todos los poderes públicos.

A esta dimensión, a la que se ha llamado independencia judicial externa, se debe unir la que mira al interior de la organización judicial. O sea, a los tribunales superiores y a los órganos de gobierno de la judicatura.

1.3. La independencia judicial no es en absoluto un valor en sí mismo. Se trata de una exigencia instrumental que tiene por objeto sustraer a cada concreto juez de condicionamientos o presiones que coarten o puedan coartar el ejercicio de la función jurisdiccional con la imprescindible imparcialidad. Requiere, pues, de normas e instituciones que le coloquen en tal posición que no deba preocuparse por la manera en que juzga y hace ejecutar lo juzgado siempre que observe al ejercer esa función la contrapartida imprescindible de la independencia que se le quiere asegurar: la sumisión estricta a la Constitución y a la Ley de la que es, por otra parte, responsable. 
Así, pues, para asegurar la independencia de cada juez, el ordenamiento asume como uno de sus principios vertebradores el de la independencia del Poder Judicial y provee a asegurarla mediante la predisposición de los elementos normativos e institucionales precisos para que esa independencia individual exista efectivamente.

El estricto sometimiento del estatuto del juez a la ley y la inclusión dentro de él de figuras como la inamovilidad y un amplio catálogo de deberes, incompatibilidades y prohibiciones sirve para eliminar la posibilidad de presiones o la existencia de situaciones de conflicto de intereses susceptibles de condicionar su actuación. Y, al mismo fin sirve la predeterminación normativa del modo en que se seleccionan los jueces, desarrollan su carrera administrativa y son retribuidos, y los supuestos constitutivos de infracción o delito que pueden cometer en el ejercicio de sus funciones y sus correspondientes sanciones.

Es sabido que para administrar el estatuto judicial y dar un sentido institucional al compromiso con la independencia judicial, nuestra Constitución, optó por crear un Consejo General del Poder Judicial, presidido por el presidente del Tribunal Supremo, a quien elige el Consejo en su sesión constitutiva.

1.4. A reserva de lo que diré al responder a la siguiente pregunta, me parece importante señalar que en todo el tiempo transcurrido desde que se constituyó el 23 de octubre de 1980 el Consejo General del Poder Judicial nadie ha podido acreditar que en España los jueces carezcan de la independencia que deben poseer. Dicho de otro modo, que en el ejercicio de la jurisdicción se sometan a imposiciones o designios procedentes de los poderes públicos.

Seguramente, se habría llegado al mismo resultado si el constituyente, en vez de optar por el modelo del Consejo de la Magistratura procedente de las experiencias francesa e italiana, principalmente, hubiera escogido otro diferente pero lo cierto es que los jueces en España están dotados de todas las garantías para ser independientes. Y lo son efectivamente pues, al margen de su integridad personal - que, debiendo presumirse, muchas veces parece ignorarse - no se hallan objetivamente en situación de ser condicionados ni, mucho menos, presionados por los gobernantes.

¿Por qué, entonces, está difundida la impresión de que los jueces españoles no son independientes? Se suele asociar la afirmación de que, siendo todos y cada uno personalmente independientes, sin embargo, el sistema no asegura objetivamente la independencia e inmediatamente se relaciona tal circunstancia con otro hecho que se da por demostrado: la politización de la justicia. A su vez, este fenómeno patológico se relaciona con el permanente debate sobre la elección de los vocales judiciales y con las disputas que se producen con motivo de algunos de los llamados nombramientos discrecionales que efectúa el Consejo General del Poder Judicial.

En efecto, la tacha de su politización se sigue asociando a la elección parlamentaria de los doce vocales de origen judicial, incluso por quienes no ven inconvenientes en que se use ese procedimiento para designar a dos terceras partes de 
los magistrados del Tribunal Constitucional. En este sentido, llama la atención que su sentencia 108/1986 se preocupara por la aplicación a la elección de esos vocales del mismo sistema mediante el que son elegidos ocho de los doce magistrados del supremo intérprete de la Constitución y no observara la misma inquietud por su propia situación. Pues bien, según la crítica más extrema, esos nombramientos discrecionales, estarían sometidos a la voluntad de los partidos políticos que mediatizan a los vocales respectivos, a los suyos, a los que han elegido y logran que orienten en el sentido que aquellos desean los nombramientos.

La conclusión inevitable a que conduce este planteamiento es la de que los nombrados discrecionalmente no serían independientes ni imparciales. E, inevitablemente, habría que concluir que, de ser todo ello cierto, no estaríamos ya ante el mero incumplimiento de la Constitución sino ante un fenómeno infinitamente más grave en el que se combinarían la infracción por parte de los miembros del Consejo de sus principales deberes con la falta de integridad de todos los que se prestasen a esa operación, incluidos los así nombrados que se manifestasen dispuestos a seguir en el ejercicio de la jurisdicción las indicaciones de quienes les propusieron. Sinceramente, creo que los hechos no permiten descripciones e interpretaciones de tal naturaleza.

1.5. Los nombramientos discrecionales son los de presidentes de Salas y de magistrados del Tribunal Supremo, los de presidentes de la Audiencia Nacional, de los Tribunales Superiores de Justicia y de sus Salas, los nombramientos de los magistrados de la Sala Civil y Penal de estos últimos que proponen las asambleas legislativas de las Comunidades Autónomas y los de los presidentes de las Audiencias Provinciales. Además, naturalmente, del nombramiento del propio presidente del Tribunal Supremo. También son un claro ejemplo de nombramiento discrecional las designaciones de los dos magistrados del Tribunal Constitucional que corresponde hacer al Consejo General del Poder Judicial y viene efectuando desde 1980.

Mientras que, significativamente, no se ha producido controversia alguna respecto de estas últimas desde 1980 a la actualidad, en cambio, es verdad que sobre algunos de los demás nombramientos discrecionales las polémicas han sido recurrentes y en diversas ocasiones la Sala Tercera del Tribunal Supremo ha anulado acuerdos de nombramientos de esta naturaleza, en general, por falta de motivación. $\mathrm{Y}$ aunque, en casi todas las ocasiones el Consejo haya vuelto a elegir, ahora ya con la necesaria motivación, a quien escogió inicialmente, ese control judicial ha hecho que deba seguir un procedimiento específico encaminado a poner de manifiesto los méritos profesionales de los aspirantes y observar reglas concretas que reducen notablemente su discrecionalidad y el riesgo arbitrariedad. El control judicial ha estrechado de manera importante el ámbito de quienes pueden ser elegidos de este modo y la publicidad que rodea a estos episodios también ayuda a que solamente se defiendan candidaturas apoyadas por currículos importantes.

De otro lado, al final, el debate que se produce en este punto tiene, muchas veces, más que ver con el peso en el Consejo de las asociaciones profesionales de 
jueces y magistrados. Y es que, habitualmente, dos de ellas — la Asociación Profesional de la Magistratura y la asociación Jueces para la Democracia- han logrado que varios de sus miembros formen parte de los distintos Consejos Generales del Poder Judicial. Así, la cuestión se traduce en si esa circunstancia ha significado o no la preferencia de los miembros de estas dos asociaciones frente a los de las demás y frente a los no asociados, para los nombramientos discrecionales y, en particular, para los de magistrados del Tribunal Supremo.

En este contexto, la pregunta que debemos hacernos es la de si, a falta del Consejo General del Poder Judicial, ¿mejoraría la independencia efectiva de los jueces españoles? ¿Serían más independientes? ¿Se acabaría el debate sobre la politización? En otras palabras, devolver al Ministerio de Justicia la administración del estatuto del juez, ¿supondría una mejora? ¿Se vería con más tranquilidad su gestión que la realizada por el Consejo? Y los nombramientos discrecionales, ¿desaparecerían? ¿Se harían solamente por antigüedad? ¿O por un concurso de méritos según baremo sin ningún margen de apreciación cualitativa? Entonces, ¿quién lo resolvería? ¿El Ministerio de Justicia? O, como se ha propuesto, en vez del Consejo, ¿lo haría una suerte de triunvirato formado por el presidente del Tribunal Supremo y dos adjuntos?

Francamente, no veo ventajas en ninguna de estas alternativas. En primer lugar, porque no comparto la idea de que los ahora nombramientos discrecionales deban hacerse mediante un concurso de méritos tasados. Un magnífico magistrado puede ser un pésimo gestor de un tribunal, por ejemplo. Y también puede darse el caso de que quien acumule numerosos méritos de esa naturaleza no sea el que más destaque por la calidad de sus sentencias. La jurisprudencia ha acentuado la exigencia de la excelencia entre los así nombrados pero no ha considerado ni acorde con la legalidad, ni conveniente, la privación de todo elemento de discrecionalidad al Consejo General del Poder Judicial.

Se trata, pues, de que no haya arbitrariedad en estas decisiones y en este respecto hay que decir que ni todos los nombramientos discrecionales efectuados por el Consejo — por los siete Consejos que se han formado hasta ahora- han sido contestados ni todos las que lo han sido han merecido el reproche judicial. Asimismo, creo que, si en vez del Consejo General del Poder Judicial, fuera el Ministerio de Justicia o una instancia restringida, ni se aumentaría el acierto ni se evitaría la polémica y, en cambio, se perdería la casi plena transparencia a la que se ha llegado en las decisiones del Consejo.

1.6. Desde el punto de vista de los condicionamientos a los que está sujeto el ejercicio de la función jurisdiccional, me parece que los más importantes, si no únicos hoy en día, son los que resultan de la posible trascendencia social de un determinado asunto, ya sea por su naturaleza, ya sea por su entidad o por las circunstancias singulares de las partes concernidas.

No me cabe duda de que los jueces están suficientemente protegidos frente a las eventuales tentaciones de los legisladores o de los gobernantes de influir en su actuación. También lo están frente a los órganos de gobierno del Poder Judi- 
cial, pues tienen estrictamente prohibido injerirse en el ejercicio de la jurisdicción y sus eventuales excesos, de producirse, cosa que, salvo algún episodio aislado no reiterado, no se ha demostrado que haya sucedido, podrían ser anulados sin particular dificultad, además de que provocarían un clamor en contra por sí solo suficiente para desanimar todo intento de perpetrarlo.

En cambio, ante las opiniones vertidas en los medios de comunicación que, con frecuencia, adjudican a jueces y magistrados etiquetas ideológicas cuando no partidistas e, incluso, anticipan en función de ellas sus decisiones en pleitos o asuntos notorios o, simplemente, elegidos para desarrollar una determinada línea editorial, ante estas y otras situaciones semejantes que pueden llegar a convertirles sin que lo hayan buscado en el centro de la atención mediática, el juez no tiene más que su propio criterio para hacerlas frente.

Puede, desde luego, acudir al Consejo General del Poder Judicial si considera perturbada su independencia, y solicitar su amparo. El Consejo lo ha concedido en algunos casos y también ha habido algún supuesto en que la Sala Tercera [sentencia de 13 de junio de 2008 (recurso 301/2005] tha anulado el otorgado porque los hechos no tenían entidad para comprometer la independencia judicial. Ahora bien, la utilidad de ese amparo, su eficacia, está directamente relacionada con la autoridad moral de la que disponga el Consejo. Si es discutida, y muchas veces lo ha sido, el apoyo que puede prestar pierde toda su virtualidad.

También pueden salir al paso las asociaciones judiciales, sobre todo, si el afectado es miembro de una de ellas, pero su carácter corporativo priva de la dimensión institucional necesaria a sus mensajes.

El sometimiento al escrutinio público es, en todo caso, una condición inherente al ejercicio de la función jurisdiccional y a la publicidad del proceso judicial. De ahí que, en general, los jueces experimentados hayan desarrollado los mecanismos para hacer frente al exceso de exposición mediática e, incluso, a las especulaciones sobre sus preferencias y decisiones, si es que se ven en esas circunstancias. Aquí, cumple un papel esencial la motivación de las resoluciones judiciales exigida por el artículo 120.3 dela Constitución y que forma parte del contenido del derecho a la tutela judicial. La claridad, la precisión y la congruencia que la Ley de Enjuiciamiento Civil exige a las resoluciones de los jueces sirven para que, además de las partes procesales, en asuntos controvertidos que saltan a las esferas de la opinión pública, cualquier ciudadano pueda conocer las razones que han guiado la actuación del juez. Cuanto mejor y más claramente se expliquen las sentencias y los autos menos deberán preocuparse quienes los firman por las opiniones que sobre ellas se formen en los espacios públicos.

1.7. En conclusión, puede afirmarse que los jueces españoles son independientes o, si se prefiere, tan independientes como los de cualquiera de los países de la Unión Europea con los que habitualmente nos comparamos. Esto, naturalmente, no significa que hayamos alcanzado la perfección, ni mucho menos. Quiere decir, únicamente, que nuestros tribunales de justicia están servidos por jueces que no están sometidos al poder político ni a los poderes sociales y actúan de 
acuerdo con su entendimiento motivado del ordenamiento jurídico al que están sujetos. Y que ayudaría mucho a despejar las sombras que a veces se arrojan sobre ellos como consecuencia de la polémica en torno al Consejo General del Poder Judicial, una convención que neutralizara políticamente este órgano por el simple procedimiento de cumplir la Constitución.

A partir de aquí, hay que aceptar que los jueces, como cualquier otro servidor público, pueden equivocarse $y$, de hecho, se equivocan algunas veces. Y que tienen sus convicciones ideológicas y sus preferencias políticas, como cualquier otra persona normal aunque, precisamente, por la sumisión a la Constitución y a la Ley que debe presidir su actuación, no pueden dejarse llevar por ellas al ejercer la jurisdicción. Además, para preservar su imagen de independencia e imparcialidad, más allá de la observancia de los deberes y prohibiciones legales encaminados a ese fin, deben ser especialmente prudentes en sus manifestaciones públicas para evitar la apariencia contraria que, de otro modo, podría crearse.

\section{ANGEL RODRÍGUEZ-DÍAZ VERGARA}

La correlación entre independencia del poder judicial y la calidad del Estado de Derecho en la actualidad puede resumirse en la «acertada síntesis» (el calificativo es de Francisco Tomás y Valiente) con la que, al poco de aprobarse la Constitución, Jorge de Esteban y Luis López Guerra resumieron para su manual la doctrina de la separación de poderes: «El principio de separación de poderes se reduce, de hecho, a garantizar la independencia de jueces y tribunales» (El régimen constitucional español, Barcelona, 1980, pág. 327).

A mi juicio, el nivel de independencia del poder judicial respecto del poder político en nuestro país dista mucho de ser el deseable, dada su trascendencia. Esta opinión no está fundamentada en datos empíricos fiables (para empezar, sería muy problemático diseñar indicadores de esa independencia), pero sí en una impresión que, creo, se encuentra bastante generalizada tanto en la doctrina como en la opinión pública. El nivel subóptimo en el que, probablemente, habría que situar la independencia del poder judicial en nuestro país contrasta con el énfasis por la independencia judicial que puede constatarse en la $\mathrm{CE}$, y que se explica fácilmente como reacción a la falta de separación de poderes durante el franquismo.

En términos teóricos, no habría mucho que temer de esta situación si los jueces hubieran llegado a reunir las características que les atribuyó Montesquieu y se hubieran limitado a ser la boca muda que sólo pronuncia las palabras de la Ley. Por el contrario, la independencia judicial es mucho más necesaria mientras más amplias sean las facultades del juez y más discrecional pueda ser el ejercicio de la actividad jurisdiccional, una ampliación de facultades inescindible de la propia evolución del Estado constitucional, que obliga al juez a ensanchar las posibilidades de interpretación de las normas cuando es necesario adaptarlas a los términos constitucionales, lo que en ocasiones le puede obligar, incluso, a apartarse de su texto. 
En definitiva, el imperio de la Constitución conduce inevitablemente a un incremento de la labor creadora del derecho por los jueces, lo que aconseja extremar la exigencia de que la independencia judicial sea respetada en todas sus posibles acepciones.

2. ¿Qué nos quiere decir sobre el sistema de composición y de funcionamiento de nuestro Consejo General del Poder Judicial desde la óptica de su despolitización? ¿Piensa que la LO del Poder Judicial 6/1985 constituyó un avance o un retroceso en cuanto a la elección de los componentes del Consejo? ¿Sugeriría algunos criterios para su posible reforma?

\section{RAFAEL BUSTOS GISBERT}

La verdad es que soy muy pesimista respecto a los sistemas de elección de cargos públicos independientes en España. Desgraciadamente no tenemos una cultura político-democrática desarrollada que impida a los actores políticos (gubernamentales o parlamentarios) nombrar a personas no competentes o a puros «clientes» políticos para este tipo de cargos porque hacerlo suponga un altísimo coste electoral. Esto es, en países con mayor tradición el nombramiento de personas demasiado fieles o no suficientemente competentes por motivos estrictamente políticos implican (o pueden implicar) un alto coste electoral para los partidos proponentes. Sin embargo, en España lejos de ser sancionado electoralmente es contemplado, desgraciadamente, como algo normal.

El sistema instaurado en 1985 tenía importantes razones detrás que quizás hoy no sean tan claras o no lo justifiquen de igual forma. Pero no ha de olvidarse que el CGPJ es un órgano de gobierno no de representación. Por ello, no parece absurdo que el nombramiento de un órgano de gobierno de un poder del Estado corresponda al Parlamento en cuanto representante del pueblo del Estado y no a una elección, directa o indirecta, de sólo una parte de los ciudadanos. Creo sinceramente que el gobierno del poder judicial no interesa solo a los jueces y magistrados, sino a todos los ciudadanos que al fin y al cabo son los «clientes» de dicho poder. Ahora bien, también es cierto, y esto habría que tenerlo en cuenta, que quienes se dedican a juzgar y ejecutar lo juzgado están afectados de manera directa y permanente por las decisiones de dicho órgano. Por ello, tampoco deberían estar totalmente excluidos de su nombramiento. Es necesario buscar soluciones más elaboradas que las propuestas en los años 80 del pasado siglo. No es ocioso resaltar que han pasado más de 30 años y parece que una revisión del sistema de nombramiento es algo ya aceptado por todos los partidos y asociaciones judiciales.

Respecto a si, en su día, constituyó un avance el sistema instaurado en 1985 he de confesar que creo que sí dada la composición del poder judicial de la época. Pero no creo que hoy en día esas razones que lo justificaban sigan vigentes. 
Especialmente negativo, creo, para la independencia del CGPJ ha sido su última reforma y la creación de vocales a tiempo completo y vocales a tiempo parcial que han de seguir desempeñando sus funciones jurisdiccionales a la vez que actúan como miembros de un órgano de gobierno que decide cuestiones básicas de los propios compañeros. No se trata solo de una cuestión de tiempo y de carga de trabajo, se trata también de una cuestión de independencia. Especialmente palmaria es la inconveniencia de la situación en el caso de los miembros no judiciales del CGPJ pues nos encontraremos a abogados en ejercicio que son simultáneamente miembros del CGPJ y que, por tanto, seguirán ejerciendo sus funciones de asesoramiento a las partes en procesos ante órganos judiciales que está encargado de gobernar. Es evidente que el número de miembros del CGPJ para un órgano de gobierno es excesivo, pero la solución legal lejos de mejorar las cosas creo que las empeora.

En lo atinente a la reforma del sistema de selección de vocales del CGPJ es obvio que el sistema de 1985 está absolutamente desprestigiado por el uso vergonzoso de la política de cuotas realizado por los partidos políticos. La pregunta es cómo evitar ese sistema de cuotas. La elección directa de los vocales por los miembros de la carrera judicial no me parece una buena idea porque, como ya hemos dicho más arriba, no puede entenderse el CGPJ como un órgano de representación de los jueces, sino como un órgano de gobierno de un poder del Estado para todos los ciudadanos y estos no han de quedar, por tanto, excluidos de su selección. Pero la elección parlamentaria, y el sistema de cuotas, ha mostrado sus debilidades. Por eso creo que habría que ir a sistemas mixtos. Así podría separarse propuesta y nombramiento. El nombramiento habrá de permanecer en sede parlamentaria estatal (pues estatal es el poder gobernado), pero dentro de un listado cerrado de candidatos propuestos por instancias lo más independientes posible y que conozcan bien a los posibles candidatos. Poniéndonos en un papel que no nos corresponde (el del legislador o el del constituyente) a mi me parece que las salas de Gobierno de los TSJ con su composición mixta (electiva y miembros natos como presidentes de las Audiencias y del TSJ) han funcionado razonablemente bien, son elegidas en función de las virtudes personales de los candidatos y no sus posiciones políticas o sus afinidades asociativas. Estas salas podrían proponer un número de candidatos limitado a los que se unirían los propuestos por la Sala de Gobierno de la Audiencia Nacional y del Tribunal Supremo hasta conferir un listado de 90 ò 100 candidatos entre los que tendría que elegir el Parlamento tras unas audiencias públicas serias y con mayorías cualificadas.

\section{JUAN FERNANDO LÓPEZ AGUILAR}

El CGPJ es hoy arquetipo de órgano constitucional aquejado de lo que podemos llamar «síndrome de fallo múltiple». Un síndrome expresivo a su vez (con gran anticipación a otros órganos) de la fatiga de materiales que aqueja desde 
hace un tiempo al rendimiento del entero edificio constitucional después de 40 años desde los pactos y acuerdos que lo hicieron posible.

Tanto así que la disfunción del CGPJ es descrita a partir de la contraindicación entre su composición (colegiada y numerosa: un total de 20 miembros, que eligen al número 21, que será su presidente y del Tribunal Supremo) y sus funciones constitucionalmente asignadas, que son claramente ejecutivas (no judiciales, sino de «gobierno» y orientación política en política judicial): baste, para comprobarlo, la lectura del art. $122 \mathrm{CE}$, en el que, a partir de las sugerencias del socialista Peces Barba en la ponencia constitucional, se conglomeran influencias del Conseil Superieur de la Constitución francesa de 1958 y del Consiglio Superiore de la Constitución italiana de 1948.

En consecuencia, he sostenido muchas veces que el CGPJ es un órgano politico (puesto que su función no es jurisdiccional, sino decisoria - nombramientos, disciplina y sanciones - y eventualmente consultiva: emite dictámenes de parte desde sus propios intereses). No es por lo tanto la «correa de transmisión de los intereses de los jueces ante otros órganos del Estado»; ni tampoco, desde luego, es una «intersindical de jueces» (trasunto de «asociaciones» de la judicatura sobre vectores ideológicos y afinidades partidarias, una lógica de la que huye el art. 128 CE). El CGPJ es, antes bien, un órgano de gobierno de la judicatura, y esa función es política.

Si por «despolitizar» se entiende prevenir y evitar la inmisión en su seno de la competición entre partidos políticos (y sus líneas de fractura), comparto el objetivo. Por eso deploro las aplicaciones prácticas de esa «partidización» sin más: la «lottizzazione alla spagnola», los «intercambios de cromos» (yo «no miro» a «los tuyos» ni «me meto en tu cuota» a cambio de que tú «no mires» ni impongas «vetos» a los «míos») y la pérdida de rigor en los supuestos de la preselección y elección de candidatos. Comparto - a expensas de un nuevo consenso o acuerdo para una reforma constitucional con mayoría suficiente (al menos $3 / 5$ de cada Cámara) — el actual esquema de elección parlamentaria de sus 20 miembros (en sus dos tramos: la componente «togada», 12 miembros, y la componente de «juristas de prestigio», otros 8 miembros).

Para su eventual reforma - a expensas de lo que resulte de un deseable (a mi juicio, imperioso) proceso de reforma constitucional profundo que debería alcanzar, por descontado, a este órganomedidas cuya combinación puede coadyuvar al rescate de un órgano constitucional como es el CGPJ, de otro modo condenado al deterioro y la pérdida de crédito institucional. Entre ellas, las siguientes: extremar el rigor y calidad de los perfiles y de los procedimientos parlamentarios diseñados para su verificación y examen («hearing» o comparecencia en la Comisión parlamentaria de Justicia); restringir la elegibilidad a magistrados veteranos del Tribunal Supremo; catedráticos de criterio contrastado en política judicial; abogados de indisputable autoridad y reputación procesional; y la aseguración de la ausencia, en todos los casos, en todas y cada una de las personas propuestas y promovidas para el órgano, de 
subordinaciones partidarias ni corporativas que susciten dudas sobre la obediencia o independencia de sus votos individuales en cada decisión (especialmente, en lo tocante a política de nombramientos). Y, por supuesto, establecer la exigencia normativa de la publicidad de cada voto individual de cada miembro del órgano. Y ello porque ninguna decisión política debe sustraerse al control de su dación de cuentas (accountability) respecto de cada ocasión en que se ejerce el poder que haya sido conferido por la ley y por la Constitución.

\section{PABLO LUCAS MURILLO DE LA CUEVA}

2.1. La solución me parece clara. Si se cumple la Constitución y la Ley Orgánica y los grupos parlamentarios se esfuerzan en elegir como vocales a miembros de la carrera judicial caracterizados por su buen hacer y a juristas de prestigio profesional reconocido y lo hacen buscando coincidir en positivo en vez de repartirse cuotas, en especial cuotas ciegas, creo que se habría acabado la ya vieja y recurrente controversia.

El Consejo es un órgano político, tiene una parcela de poder no muy amplia pero sí muy importante pues, además de sus otros cometidos, sobre todo de la inspección y del régimen disciplinario de los jueces, le corresponde la elección del Presidente y de los magistrados del Tribunal Supremo y los otros nombramientos discrecionales antes mencionados. Si se tiene presente que su Sala Segunda enjuicia a los miembros del Gobierno y de las Cortes Generales y que su Sala Tercera controla los actos del Consejo de Ministros y que las Salas de lo Civil y Penal de los Tribunales Superiores de Justicia juzgan a los aforados autonómicos y las Salas territoriales de lo Contencioso-Administrativo revisan las actuaciones de los Consejos de Gobierno de las Comunidades Autónomas, se comprende que sea apetecible políticamente estar presente en él.

Pero la Constitución ha erigido al Consejo General del Poder Judicial en salvaguarda de la independencia judicial y quiere que sus ocho miembros no judiciales sean elegidos entre juristas de reconocida competencia - es el único criterio cualitativo que nos da- con más de quince años de ejercicio. Y que la elección sea por mayoría de tres quintos para que no haya imposiciones de parte. La exigencia de que los otros doce vocales sean miembros en activo de la carrera judicial refuerza el perfil técnico de los vocales y les añade el rasgo de la independencia que cabe esperar de los jueces. Son motivos suficientes para saber que el constituyente quiso que para este órgano se elija a quien posea prestigio profesional y se le reconozca criterio propio y resolución para mantenerlo. Aquí está la clave.

Como decía el profesor Giuseppe Ugo Rescigno, el problema no es la lottizzazione, es decir, el reparto de cuotas en la formación de los órganos constitucionales sino la lottizzazione mal hecha, la que busca partidarios o se hace desentendiéndose cada uno de a quien propone el otro con tal de que acepte al propio, sin 
consideración alguna a la excelencia profesional y a la calidad de los propuestos. Esta lógica de las cuotas ciegas es la causa principal del deterioro de la imagen del Consejo General del Poder Judicial, más acusada cuanto menos se hayan tenido en cuenta los elementos cualitativos queridos por la Constitución. En cambio, cuando el consenso se ha orientado en sentido positivo el resultado ha sido totalmente distinto. Una buena muestra de que es posible hacerlo así la encontramos en la elección del cuarto Consejo General del Poder Judicial.

Pero en la mayor parte de los casos no se ha aplicado el artículo 122 de la Constitución respetando su espíritu y sus determinaciones y el resultado está a la vista.

A pesar de ello, creo que el procedimiento menos malo es el que pone en manos de las Cortes Generales la designación por mayoría cualificada de los veinte vocales y, si se combina, respecto de los doce vocales de origen judicial, con formas de propuesta o aval de la carrera judicial, mejor. Pero deben ser las Cortes Generales, que representan al pueblo español, quienes decidan. Con todo el respeto que merece un cuerpo funcionarial como la carrera judicial y las asociaciones profesionales que encuadran a la mitad de sus integrantes, no me parece que estén legitimadas para reclamar la facultad de elegir a la mayor parte de los integrantes de un órgano constitucional.

Y, como he dicho antes, no creo que devolver al Ministerio de Justicia, o encomendar a otras instancias por crear, las decisiones sobre el estatuto de los jueces nos depare mejoras en términos de independencia judicial y ausencia de debate sobre la politización o el condicionamiento partidista.

Por otro lado, frente a la afirmación de que la mejor razón para volver a la elección judicial de los doce vocales jueces o magistrados es que el sistema implantado en 1985 no ha funcionado, diré que no es cierto. Ese sistema funcionó razonablemente bien en 1996 y en todas las ocasiones en que se ha aplicado sin controversia para designar a magistrados del Tribunal Constitucional.

2.2. Soy consciente de que la postura que mantengo tiene en contra a las asociaciones judiciales y otros colectivos formados en el seno de la carrera judicial, que hay documentos promovidos en el seno del Consejo de Europa que recomiendan que para garantizar la independencia de la autoridad competente para seleccionar a los jueces, al menos la mitad de sus miembros han de ser elegidos por sus pares, como la Recomendación CM/Rec (2010) del Comité de Ministros a los Estados miembros del Consejo de Europa de 17 de noviembre de 2010. Y el Consejo Consultivo de Jueces Europeos aprobó en su undécima reunión plenaria del 17 al 19 de noviembre de 2010 una Magna Carta de los jueces según la cual los Consejos de la Magistratura han de estar compuestos solamente por jueces o, al menos, en su mayor parte, elegidos por sus pares.

La reciente sentencia de la Sección Cuarta del Tribunal Europeo de Derechos Humanos de 21 de junio de 2016 (recursos 55391/13 y 7404/13), dictada en el asunto Ramos Nunes de Carvalho e Sá contra Portugal, da cuenta de esas posiciones. Es interesante para lo que aquí estamos considerando porque ampara a un 
juez portugués sancionado por el Consejo Superior de la Magistratura, en acuerdo confirmado por el Tribunal Supremo. Y falla a su favor, tras examinar las condiciones de independencia que ha de reunir un órgano encargado de ejercer la potestad disciplinaria sobre los jueces. Concluye que, para que pueda ser considerado independiente e imparcial es necesario que un número importante de sus miembros sean jueces, tal como prescribe la Carta Europea sobre el Estatuto de los Jueces. Y, tras observar lo que dice la Recomendación antes mencionada y la Magna Carta de los Jueces, comprueba que, conforme a la legislación portuguesa, en la composición del Consejo Superior de la Magistratura que sancionó al recurrente los jueces eran minoría y, en consecuencia, la sentencia concluye que la independencia y la imparcialidad del Consejo Superior de la Magistratura estaban en cuestión. Luego, comprueba que el control de la legalidad del acuerdo sancionador efectuado por el Tribunal Supremo fue meramente formal e insuficiente por no revisar si, efectivamente, el comportamiento del recurrente fue incompatible con el deber de diligencia de un magistrado. En fin, el Tribunal de Estrasburgo, constata que el Tribunal Supremo no permitió que el sancionado presentara un testigo y unos documentos en audiencia pública y faltó así a las exigencias de contradicción y transparencia que debió observar. Esas tres razones le llevan a fallar a favor del recurrente.

Pues bien, es importante destacar que, pudiendo haberlo hecho, el Tribunal Europeo de Derechos Humanos no se ha pronunciado sobre la manera en que se han de elegir los jueces miembros de los Consejos de la Magistratura. Y, por otro lado, que en nuestro ordenamiento son, como sabemos, más numerosos los vocales judiciales que los no judiciales y que esa relación se mantiene en todas las formaciones del Consejo General del Poder Judicial. También conviene decir que el control efectuado por la Sala Tercera del Tribunal Supremo sobre los acuerdos de cualquier naturaleza del Consejo, incluidos los sancionadores, es riguroso y, siempre que se den las condiciones procesales para ello, entra en el fondo de la controversia. El examen de las numerosas sentencias dictadas al respecto pone de manifiesto que se trata de un control judicial efectivo el que se realiza.

2.3. Hablando de la composición del Consejo General del Poder Judicial, tras la reforma de la Ley Orgánica del Poder Judicial por la Ley Orgánica 4/2013, de 28 de junio, he de decir que la nueva regulación del procedimiento de designación de los vocales, la previsión de que pueda funcionar un Consejo con la mitad de sus miembros renovados y la otra mitad en funciones y, sobre todo, la transmutación que ha operado en el órgano del gobierno del Poder Judicial reduciéndolo, en realidad, a su Comisión Permanente e instituyendo dos clases de vocales, los que forman parte de ésta y ejercen la plenitud de las funciones del órgano constitucional, y los demás que solamente intervienen en una parte de ellas, es un claro ejemplo de la desnaturalización por el legislador de una institución y de su sometimiento a las desviaciones de la práctica política.

Asumir la instrumentalización por los grupos parlamentarios del procedimiento de designación de vocales, pues no otra cosa supone aceptar la renovación 
parcial del Consejo, no es, pues, una buena solución. Introduce, además, de manera forzada un criterio eventual de conformación transitoria del órgano de gobierno.

La renovación parcial de los componentes de órganos colegiados no es desconocida. La Constitución la impone respecto del Tribunal Constitucional y se ha justificado esa forma de proceder con el argumento de que así se introduce un elemento de gradualidad importante para que, con los nuevos miembros, lleguen al Tribunal Constitucional nuevas perspectivas o sensibilidades en correspondencia conlas que prevalecen en la sociedad. No obstante, lo que es, sin duda, un buen criterio para un órgano jurisdiccional como el Tribunal Constitucional no tiene por qué serlo para un órgano gubernativo ni siquiera, con carácter provisional, a título excepcional y para evitar males mayores.

Me parece que hubiera sido mejor otra respuesta al bloqueo de la designación parlamentaria. En particular, pienso en aquellas que desapoderen a unos grupos parlamentarios que han sido incapaces de cumplir con su función constitucional de integrar un órgano constitucional pues la instrumentalización partidista de un procedimiento garantista no puede revertir en beneficio de quien la lleva a cabo ni tampoco en perjuicio del buen funcionamiento del Consejo General del Poder Judicial. En este sentido, creo que se debe considerar, por ejemplo, la posibilidad de sustituir la elección de los vocales judiciales por un sorteo a realizar por las cámaras entre los candidatos avalados por los jueces y por las asociaciones judiciales si, transcurrido un plazo prudente, el Congreso o el Senado no han cumplido el deber que les impone la Constitución. Esta solución podría establecerla el legislador.

Hacer algo parecido con la elección de los ocho vocales juristas choca con la exigencia constitucional de la mayoría de tres quintos. Por tanto, para salir del punto muerto que pudiera producirse haría falta modificar el artículo 122.3 de la Constitución. Visto lo sucedido en el pasado, no debería renunciarse a intentarlo para extender a la elección de la totalidad de los integrantes del Consejo General un procedimiento objetivo sobre el que no tengan capacidad de decisión unos grupos parlamentarios que en un tiempo razonable no hayan logrado ponerse de acuerdo sobre doce jueces y ocho juristas. No se puede aceptar que entre los más de cinco mil miembros de la carrera judicial y los numerosos juristas prestigiosos con más de quince años de ejercicio que hay en España no sea posible encontrar a doce de los primeros y ocho de los segundos que merezcan el beneplácito de las cámaras.

2.4. Por otro lado, la concentración de las decisiones en la Comisión Permanente la cual, salvo en los casos de nombramientos discrecionales, aprobación de reglamentos e imposición de sanciones, agota la vía administrativa y la limitación de las competencias del Pleno a los asuntos tasados relacionados en el artículo 599 de la Ley Orgánica del Poder Judicial supone una modificación del régimen querido por la Constitución para el Consejo General del Poder Judicial. No hay en el texto fundamental nada que permita distinguir la calidad de unos y 
otros vocales ni, mucho menos, dividirlos en dos clases: los que dirigen día a día el Consejo desde la Comisión Permanente y los que acuden al Consejo una o dos veces al mes para las reuniones del Pleno o de las comisiones que solamente conocen de parte de las funciones del Consejo.

En estas modificaciones legislativas y en otras traídas por la Ley Orgánica 4/2013, como las correspondientes al notorio reforzamiento de la posición del Presidente del Tribunal Supremo, vía atribución de cometidos y de creación de órganos de apoyo, se percibe la idea de que son demasiados 20 vocales, los queridos por la Constitución, para gobernar el Poder Judicial y una concepción «ministerial» del órgano de gobierno del Poder Judicial en la que el Presidente viene a convertirse en una suerte de «ministro».

Puede, ciertamente, ser verdad que no hagan falta tantos vocales pero, si se llegara a esa conclusión, la solución no es manipular la institución con regulaciones sin apoyo constitucional, sino, sencillamente reformar en ese punto la Constitución para reducir el número de los que componen el Consejo.

Por otro lado, no creo que potenciar aún más la dimensión ejecutiva, gubernativa, del Presidente del Tribunal Supremo — «ministerializarlo»— sea una buena solución. Precisamente porque preside el Tribunal Supremo y representa el Poder Judicial, el Consejo debe organizarse de manera que sea posible su funcionamiento sin que dependa de la posición jerárquica del Presidente. A este se le debe preservar, evitándole las ocupaciones cotidianas, y, en cambio, se ha de realzar su autoridad, su posición institucional, lo cual no pasa necesariamente por acumular o concentrar en él las responsabilidades de gestión del Consejo.

\section{ANGEL RODRÍGUEZ-DÍAZ VERGARA}

En 1985, la reforma del procedimiento de designación de los vocales del CGPJ respondió a la necesidad de acelerar la renovación y «democratización» del poder judicial, cuya cúpula seguía siendo prácticamente la misma que en tiempos de la dictadura. Hoy en día, tras treinta años de aprobación de aquella reforma, y no estando presente ya aquella necesidad, creo que puede afirmarse que el mantenimiento de la elección parlamentaria de todos los miembros del Consejo tendría más de retroceso que de avance. Me permito reproducir aquí algunos fragmentos de la respuesta que a una pregunta similar di para le encuesta sobre el control jurídico del poder que apareció en el número 31 (2013) de Teoría y Realidad Constitucional:

«La decisión, vigente con ligeras variables desde 1985, de encomendar el gobierno del Poder Judicial a un órgano constitucional elegido en su totalidad por las Cámaras, siendo como se sabe una opción plenamente constitucional, habría exigido, en palabras del TC, ser muy conscientes de que la «lógica el Estado de Partidos» incrementaba el riesgo de que de ese modo las Cámaras, a la hora de efectuar sus 
propuestas, actuaran «con criterios admisibles en otros terrenos, pero no en éste, atiendan sólo a la división de fuerzas existente en su propio seno y distribuyan los puestos a cubrir entre los distintos partidos, en proporción a la fuerza parlamentaria de éstos» (STC 108/1986 F.J. 13º). Un riesgo que habría aconsejado la implementación de algunas medidas correctoras que, sin embargo, no han sido tomadas a lo largo de todos estos años. Pues bien, el riesgo que en 1986 el TC calificó como «probable», aunque no en grado suficiente como declarar inconstitucional la reforma de la LOPJ que lo instauró, puede hoy ser plenamente ratificado. Nada parece indicar que en el futuro pueda enmendarse sino es cambiando de modelo, lo que a mi juicio pasaría por alguna fórmula de incremento de la designación corporativa».

En definitiva, cuando en 1985 nos enfrentamos a la cuestión de la designación parlamentaria de la totalidad de los miembros del Consejo lo hicimos desde unos determinados postulados teóricos que pueden seguir estando vigentes en la actualidad, pero, por razones obvias, sin saber cómo ese modelo iba a funcionar en la práctica. El pobre balance que puede hacerse al respecto abona la tesis de que, probablemente, no podía funcionar de otro modo.

3. ¿Considera que podría llegar a preocupar la neutralidad del CGPJ en materia de ascensos a juzgados sensibles como los de Instrucción de la Audiencia Nacional o a salas de lo penal importantes como la de los TSJ de las CCAA o del Tribunal Supremo?

\section{RAFAEL BUSTOS GISBERT}

No creo que pueda llegar a preocupar. Creo que ya preocupa. Aunque quizás esto no sea del todo justo. Lo cierto es que en el sistema de nombramiento puede que existan motivos para la preocupación puesto que las afinidades ideológicas y personales han jugado y juegan un papel importante. Pero hay que tener en cuenta una serie de factores que creo que a menudo se olvidan simplificando el problema del nombramiento y analizando desde lógicas exclusivamente políticas que no se corresponden, o al menos no totalmente, con la lógica profesional dentro del poder judicial. Entre estos factores deberíamos destacar:

- Son jueces los seleccionados y son jueces los que mayoritariamente seleccionan. Esto es, se nombran a personas que llevan inscritos en su código genético la sujeción a la ley y por mucha simpatía o afinidad que puedan tener con un grupo político u otro normalmente eso no condicionará de manera determinante el ejercicio de su función jurisdiccional.

- La ley establece una serie de requisitos objetivos que asegura que no ya los nombrados, sino los propios candidatos tengan un buen nivel demostrado 
en el ejercicio de la jurisdicción. Esto es, aunque la promoción pueda estar influida por factores exógenos, lo cierto es que los candidatos, todos ellos, tendrán un buen nivel en cuanto a su trayectoria profesional. Y un buen nivel en el ejercicio de la función jurisdiccional supone una buena defensa de la propia independencia frente a presiones externas. Por ello, podríamos decir que existe una suerte de filtro previo que asegura una fuerte capacitación en los propios sujetos entre los que el CGPJ ha de elegir.

- Los nombramientos del CGPJ son controlados con sumo cuidado por la Sala Tercera del TS que los anula con cierta frecuencia obligando al CGPJ a una serie de deberes de motivación vinculados a los principios de mérito y capacidad que disminuyen su discrecionalidad y alejan los riesgos más graves de arbitrariedad.

- En particular desde el último Consejo las entrevistas previas a los nombramientos son grabadas y resultan accesibles para todos los ciudadanos lo que introduce elementos de transparencia en la promoción que no deben ser desdeñados.

- En último lugar, aunque no en importancia, me resulta complicado aceptar que como regla una vez nombrados los magistrados de esos altos tribunales se dejen influir en el ejercicio de la jurisdicción de alguna manera por factores exógenos. En esta dirección creo que la conciencia de la propia independencia es un valor enormemente arraigado en la carrera judicial que en muy raras ocasiones va a poder ser puesto en cuestión en la práctica de los tribunales.

En definitiva no creo que el sistema de nombramiento en sí mismo sea desastroso, pese a que a menudo discrepe profundamente de algunos y de que, eventualmente, se hayan producido disfunciones muy acusadas. El problema es que algún órgano tendrá que hacer estos nombramientos y que los mismos no pueden basarse sólo en el criterio de antigüedad por lo que algún margen habrá de dejarse al órgano designante. Por ello, posiblemente el problema no será tanto del sistema para realizar estos nombramientos como de la sospecha de parcialidad y politización que pesa sobre el propio CGPJ que ensombrece y tiñe de desconfianza cualquier ejercicio de sus funciones.

Más preocupante me parece el nombramiento de magistrados de los TSJ por los parlamentos autonómicos en relación con la siguiente pregunta.

\section{JUAN FERNANDO LÓPEZ AGUILAR}

Por supuesto. No sólo «podría llegar a preocupar»: preocupa, efectivamente. Y preocupa desde hace mucho. Deploro particularmente el enraizamiento (y la fundamentación) de la sospecha genérica de sesgo corporativo en nombramientos 
en esos órganos en la cúpula de nuestro sistema judicial. No hablo solo, en este punto, de las respectivas preferencias ideológicas o lato sensu políticas, sino de las desviaciones obedientes a las afinidades y a los eventuales cálculos personales, profesionales y vitales, de los miembros judiciales del CGPJ, decisivos a menudo de «ascensos» en puestos «sensibles».

\section{PABLO LUCAS MURILLO DE LA CUEVA}

3.1. A los Juzgados Centrales de la Audiencia Nacional se accede por concurso, lo mismo que a su Sala de lo Penal y a las Salas de lo Civil y Penal de los Tribunales Superiores de Justicia. De estas últimas sólo son de nombramiento discrecional sus presidentes —que son los presidentes de los Tribunales Superiores de Justicia - y los magistrados propuestos por las asambleas legislativas de las Comunidades Autónomas, es decir, uno de cada tres. También son de nombramiento discrecional el presidente de la Sala de lo Penal de la Audiencia Nacional y el presidente y los magistrados de la Sala Segunda del Tribunal Supremo.

Respecto de los llamados magistrados autonómicos, el Consejo General del Poder Judicial ya dejó claro hace veinte años que no está vinculado por la preferencia expresada por la asamblea proponente en favor de uno de los candidatos y que puede devolver la propuesta si no considera idóneo a ninguno de los incluidos en ella. Y la Sala Tercera del Tribunal Supremo ha confirmado la facultad del Consejo de hacer efectivos los límites que resultan de la Ley Orgánica del Poder Judicial para la propuesta parlamentaria autonómica, si bien le ha exigido que motive sus decisiones al respecto[sentencia del pleno de la Sala Tercera de 29 de mayo de 2006 (recurso 137/2005)].

Y, por lo que hace a los presidentes de Tribunal Superior de Justicia y al presidente de la Sala de lo Penal de la Audiencia Nacional, han sido varias las ocasiones en que se ha impugnado la elección efectuada por el Consejo General del Poder Judicial. De hecho, la nueva jurisprudencia que ha llevado a un control más intenso de la actuación del Consejo General del Poder Judicial en estos nombramientos, comenzó con el de un presidente de la Sala de lo Penal de la Audiencia Nacional[sentencia del pleno de la Sala Tercera de 29 de mayo de 2006 (recurso 309/2004)].

Ahora bien, esa misma jurisprudencia que ha subrayado la búsqueda de la excelencia que ha de presidir estos nombramientos y, en consecuencia, ha extremado las exigencias de motivación que debe observar el Consejo al hacerlos, ha admitido, cuando de cargos gubernativos se trata - y las presidencias de Tribunal Superior o de la Sala de lo Penal de la Audiencia Nacional o de la Sala Segunda Tribunal Supremo lo son-que entre los elementos de valoración figure el de la sintonía o proximidad de los planteamientos gubernativos defendidos por el candidato propuesto con los fijados por el propio Consejo General del Poder Ju- 
dicial [sentencia de la Sección Séptima de la Sala Tercera de 5 de febrero de 2010 (recurso 72/2005) y la reciente del pleno n. $\left.{ }^{\circ} 1033 / 2016\right]$.

Por otro lado, importa destacar, a propósito de los nombramientos de magistrados de la Sala Segunda del Tribunal Supremo que hasta ahora no se ha impugnado el nombramiento de ninguno de ellos. Mejor dicho, solamente se ha impugnado uno pero no por cuestionar al nombrado sino por entender que la plaza ofrecida debió ser reservada para especialistas. Me parece significativo porque han sido recurridos nombramientos de magistrados de las otras cuatro Salas, en especial de la Tercera y la Cuarta.

3.2. Aclarado lo anterior y en respuesta a la pregunta de si se vería comprometida la neutralidad del Consejo General del Poder Judicial por alguno de estos nombramientos discrecionales en Salas de lo Penal, hay que decir que solamente habría motivos para que eso sucediera si el nombramiento en cuestión se apartara de las exigencias de mérito y capacidad que se vienen considerando imprescindibles.

En cualquier caso, no se debe olvidar el deber que la Ley impone a los jueces de abstenerse en los supuestos definidos legalmente y la facultad de las partes de recusarlos si consideran que se da alguno de ellos. Abstención y recusación son figuras que miran a asegurar la imparcialidad judicial. Importa destacar al respecto que, al margen de la concurrencia de las causas tasadas previstas en la Ley, se ha ido afianzando, a partir de la jurisprudencia del Tribunal Europeo de Derechos Humanos, la preocupación no sólo por la imparcialidad subjetiva del juez, sino también por la que se ha llamado su imparcialidad objetiva. Es decir, aquella que se ve comprometida ante la opinión pública, ante la sociedad, si de los hechos concurrentes puede razonablemente desprenderse una apariencia de parcialidad del juzgador.

Esta circunstancia puede producirse no sólo respecto de jueces que hayan sido objeto de un nombramiento discrecional, sino también de los que han obtenido destino por concurso. Así, recientemente, en la Sala de lo Penal de la Audiencia Nacional se han aceptado recusaciones en causas en las que es parte un partido político, de dos magistrados designados en su día vocales del Consejo General del Poder Judicial a propuesta de parlamentarios de esa formación política.

\section{ANGEL RODRÍGUEZ-DÍAZ VERGARA}

Sí, sin duda.

Debemos tener en cuenta que el problema de la independencia del poder judicial en su conjunto puede llegar a afectar al de la imparcialidad de los jueces. Hay que comenzar reconociendo que la CE no garantiza de modo explícito la imparcialidad judicial: ésta no aparece ni en la descripción del estatuto constitucional de los jueces y magistrados (que se definen como independientes, inamovibles y responsables, pero no «imparciales»), ni entre las garantías del derecho 
fundamental a la tutela judicial efectiva (pues entre las que expresamente se reconocen por la Constitución no se encuentra la del juez «imparcial»). La omisión de la imparcialidad judicial en el texto de la CE se ha llegado a calificar de una auténtica «paradoja constitucional» (Rafael Jiménez Asensio; la paradoja es aún más evidente si tenemos en cuenta que la imparcialidad sí se predica del ministerio fiscal o de los funcionarios públicos) y puede probablemente explicarse por el hecho de que el constituyente estuviera preocupado, sobre todo, por garantizar la independencia del juez.

Es cierto que independencia e imparcialidad no son exactamente lo mismo: la primera tiene que ver con la relación de los jueces con otros poderes del Estado, con respecto a ninguno de los cuales deben encontrarse en una relación de subordinación; la segunda, con la exigencia de que el juez ejerza su actividad jurisdiccional sin prejuzgar su resultado, sin tener ninguna relación con las partes del proceso y sin mostrar ningún interés en favorecer o perjudicar a alguna de ellas. La independencia garantiza que los miembros del poder judicial ejercerán sus funciones sin obedecer instrucciones de ningún otro; la imparcialidad, que no les animará en ello otro objetivo que la impartición de justicia.

Ahora bien, independencia del poder judicial e imparcialidad del juez se entrecruzan en temas como el que suscita esta pregunta. Es precisamente en estos casos donde la apariencia de imparcialidad del juez (y nada más peligroso para ésta que el nombramiento por un órgano cuya independencia está puesta en cuestión) es tan necesaria como la imparcialidad misma.

4. ¿Qué valoración le merece el que España sea con mucho el Estado miembro de la Unión Europa con mayor número de políticos aforados? ¿El que los responsables públicos de las Comunidades Autónomas estén aforados ante el TSJ de la propia Comunidad, puede motivar el que aquellos busquen incrementar las competencias autonómicas respecto de los juzgados y tribunales sitos en su territorio? ¿'Sugeriría usted la supresión total o parcial de los aforamientos?

\section{RAFAEL BUSTOS GISBERT}

En este tema, como en muchas de las cuestiones planteadas por esta encuesta, estamos demasiado apegados a los temores existentes en el momento de aprobarse la Constitución. Debe recordarse que entonces no se produjo una renovación generalizada de la composición del poder judicial lo que despertaba enormes recelos en una clase política que sentía una gran desconfianza hacia jueces y magistrados que ocupaban sus puestos ya en la época de la dictadura. El temor a que el poder judicial pudiera actuar contra los miembros de los poderes legislativos y ejecutivos democráticos recién instaurados era un temor real y fundado que, sin embargo, no tiene hoy base real. Resulta creo, por ello evidente que desaparecida 
la razón de muchos de los aforamientos (evitar eventuales persecuciones judiciales a cargos democráticos) debamos reducir su número, si bien la práctica de nuestra democracia pueda aconsejar también incluir algunas cautelas para evitar que acusaciones populares partidistas o sesgadas políticamente puedan iniciar pleitos por motivos puramente electorales.

Dicho esto creo que los aforamientos pueden reducirse sensiblemente, así como, por cierto, reducir también de manera relevante la inmunidad parlamentaria y que deje de ser necesaria la autorización para procesar a un miembro de un parlamento. Ahora bien, posiblemente para evitar caer en el otro extremo de la balanza quizás podría mantenerse el aforamiento en sentido estricto (no la inmunidad) para delitos vinculados al ejercicio de cargo electivo o de gobierno. No es lo mismo, creo, juzgar un delito común en el que cualquier juez o tribunal está en condiciones de juzgar a un parlamentario a pesar de la presión de la opinión pública que juzgar delitos vinculados a corrupción política o similares.

Debe destacarse en este punto el último párrafo de la respuesta a la pregunta anterior porque creo no ha sido apuntado suficientemente. Me refiero al nombramiento de jueces del TSJ por los parlamentos autonómicos. Es el propio TSJ el encargado de juzgar a los aforados de la Comunidad Autónoma y eso da lugar a situaciones tan delicadas como que el magistrado nombrado por el parlamento autonómico, a propuesta y con el apoyo del partido mayoritario, instruya causas penales por corrupción contra miembros de ese mismo partido o incluso contra el presidente de la Comunidad Autónoma que personalmente se involucró en conseguir su nombramiento. Desgraciadamente la práctica en las Islas Baleares, en Valencia, en Andalucía o en Cataluña muestra que esta situación no es un supuesto de laboratorio.

\section{JUAN FERNANDO LÓPEZ AGUILAR}

Soy muy consciente, desde hace ya mucho tiempo, del abrupto (y brutal) deterioro padecido por la «percepción» de «la política»y de «los políticos»a rebufo de la crisis desatada en 2008 y cronificada desde entonces por su pésimo, abyecto y antisocial manejo. Una gestión de la crisis ciertamente catastrófica, que se ha impuesto, no se olvide, a escala paneuropea, por una correlación de fuerzas contra la que he combatido y continúo combatiendo intelectual y políticamente durante todos estos años.

En este contexto tan adverso sé muy bien que es arriesgado asumir la lógica histórica de la que procede la técnica del «aforamiento», que ha de ser entendida no como «privilegio» ni «prebenda», sino como una garantía razonable y razonada de la función asociada a un cargo, orientada a impedir la litigación orientada a eliminar sin filtro a los adversarios políticos por una mera acusación, alegación de cualquier rango o acción procesal a ese efecto: quitarse de en medio al cargo público mediante el sencillo expediente de acusarle o «imputarle» cualquier hecho ilegal o deshonroso. 
Sí, es cierto asimismo que la «nómina» de aforados en España es demasiado abultada: conviene reconsiderarla precisamente en sus segmentos judiciales y fiscales (los más cuantiosos: unos 10.000 en total), autonómicos (otros 3.000), y, por qué no, en el estrato de las instituciones estatales (órganos constitucionales).

A cambio, será imprescindible reforzar las garantías de la presunción de inocencia para evitar descabalgar de cargo público a cualquiera, en cualquier circunstancia y en cualquier momento, por la mera admisión a trámite de un escrito procesal.

\section{PABLO LUCAS MURILLO DE LA CUEVA}

Es verdad que el aforamiento no es una institución extendida en el Derecho comparado y que, en principio, parece pugnar con el principio de igualdad e, incluso, con el derecho a la tutela judicial efectiva. También es cierto que las mismas garantías de imparcialidad y sumisión estricta a la Constitución y a la Ley se han de encontrar en todos los juzgados y tribunales y no son patrimonio exclusivo del Tribunal Supremo. De otro lado, hay que reconocer que, en el caso del enjuiciamiento en única instancia por su Sala Segunda, el aforado carece de la posibilidad de recurrir a un órgano judicial superior en el caso de ser condenado.

Obviamente, los argumentos de constitucionalidad decaen cuando es el propio texto fundamental el que prevé esos aforamientos. Y, si nos limitamos a la Constitución, son solamente los miembros de las Cortes Generales y los del Gobierno los que reciben esta garantía. Los demás aforamientos están en los estatutos de autonomía o en las leyes.

Por otro lado, mientras la Constitución solamente establece el fuero a efectos penales, la Ley Orgánica del Poder Judicial lo amplía a la responsabilidad civil de un amplio catálogo de titulares de cargos públicos (artículo 56.2). Incluso, conocimos en su día el intento de ampliar la figura de la inmunidad parlamentaria a los procesos civiles de protección del honor, la intimidad personal y familiar y la propia imagen regulados por la Ley Orgánica, 1/1982, de 5 de mayo. Intento frustrado por el Tribunal Constitucional en sus sentencias 243/1988 y 9/1990.

Creo que son esos aforamientos externos a la Constitución los que deben ser revisados con el natural criterio restrictivo. Análisis que ha de hacerse caso por caso, valorando las posibles razones de tipo funcional que pudieran aconsejar mantener algunos de ellos.

\section{ANGEL RODRÍGUEZ-DÍAZ VERGARA}

En mi opinión, es necesaria una profunda racionalización de todas las prerrogativas parlamentarias, no sólo la de aforamiento, pero no creo que ello deba conducir, necesariamente, a su supresión. 
Más bien al contrario: la conveniencia en mantener cierto tipo de aforamiento se incrementará, a mi juicio, si se consolidan los códigos éticos en el interior de los partidos que exigen adelantar la exigencia de responsabilidad política en los casos de corrupción al momento en el que sus cargos electos sean investigados por un órgano judicial. De este modo, en la práctica, se está dando a los jueces de instrucción la capacidad para decidir sobre el cese en sus funciones de cargos públicos representativos, con el consecuente riesgo de instaurar, de manera indirecta, una suerte de «revocatorio judicial» de los cargos electos. Pues bien, ese riesgo se vería considerablemente reducido si se siguiera reservando para los Tribunales Superiores de Justicia, o para el propio Tribunal Supremo, la facultad en exclusiva de investigar a determinados cargos públicos representativos. Es decir, si no desapareciera la prerrogativa de aforamiento.

No creo, en todo caso, que la solución al problema del escaso despliegue entre nosotros del principio de responsabilidad política pueda venir de la mano de una excesiva judicialización. Por el contrario, atribuir a todos los jueces de instrucción la capacidad para poner en marcha, aunque sea de manera indirecta, los mecanismos de exigencia de esa responsabilidad redundará inevitablemente en una aún mayor judicialización de nuestra vida política.

Quizá una posible solución a este problema podría venir yendo en la dirección opuesta, es decir, no retrasando la exigencia de responsabilidad política hasta el momento de la investigación judicial, sino adelantándola. Puede que de ese modo la responsabilidad política pudiera funcionar con la necesaria autonomía de la responsabilidad penal.

5. Como sabemos el artículo 118 CE dispone que «Es obligado cumplir las sentencias», pero a la vez el art. 62, i) reconoce "el derecho de gracia con arreglo a la ley», a lo que se añade el que se ha mantenido vigente la Ley de 18 de junio de 1870, por lo demás, modificada por la Ley 1/1988 que eliminó la motivación preceptiva en los indultos parciales. ¿Qué valoración le merece esta legislación sobre el indulto y el uso que de la misma puede hacer cada Gobierno? ¿Nos propondría alguna reforma normativa?

\section{RAFAEL BUSTOS GISBERT}

El derecho de gracia es una válvula de seguridad que permite resolver situaciones de justicia material sin afectar a la vigencia del Estado de Derecho. No es, creo, a priori, un problema su existencia, ni su uso si es moderado y de acuerdo con pautas razonablemente prestablecidas. La ley ciertamente es muy antigua y la reforma de 1988 no puede considerarse particularmente afortunada por lo que una nueva regulación parece necesaria para evitar arbitrariedad y, sobre todo, que pueda hacerse un uso torticero favorable a condenados cercanos a la mayoría gu- 
bernamental. La reforma habría de prever los supuestos en los que el derecho de gracia no puede ejercerse (delitos excluidos en su caso, tiempos de condena mínimos cumplidos) y garantías mínimas para asegurar un procedimiento transparente en el que pudieran intervenir tanto el ministerio público como las víctimas de los delitos.

\section{JUAN FERNANDO LÓPEZ AGUILAR}

A pesar de que, en efecto, la ley de indulto en vigor (1870) es la de más antigua data en el ordenamiento (junto a la del Notariado, de 1862), esta cuestión es bien reciente, más de lo que parece.

Hace tan sólo 10 años no existía ninguna alerta significativa ni una discusión política de prioridad al respecto: ningún partido con opciones de elegibilidad llevaba en su programa electoral la derogación o reforma de tan vetusta ley de indulto; no había polémica política ni demanda social (salvedad hecha, acaso, de aquel notorio «caso de indulto prodigioso» por el que el Gobierno del PP dio cobertura en 2001, bajo el paraguas de un pretextado jubileo, dentro del pelotón de un total de 1230 indultos supuestamente «individuales», puesto que la Constitución prohíbe los «indultos generales» (art. 62.i CE); aunque no prohíba, por cierto, las amnistías por ley... a expensas de los principios de igualdad ante la ley y seguridad jurídica).

Antes que nada, a este respecto, conviene hacer, como en todo, un poco de pedagogía: cada indulto que se acuerda en Consejo de Ministros (en forma de Real Decreto) debe venir precedido de una tramitación completada por su documentación preceptiva. La «gracia» a la que se refiere la lexicología arcaizante no equivale en ningún caso a la revisión ni a la «enmienda» o corrección, por parte del Ejecutivo, de la decisión judicial de condena penal conforme a un fallo o veredicto de culpabilidad tras un «juicio debido con todas las garantías»: incorpora solamente la condonación (parcial) de una parte de la pena impuesta, desde el entendimiento de que procede por razones de política criminal (la gestión de los recursos punitivos del Estado) o política penitenciaria (mediante la ponderación acerca de la conveniencia u oportunidad de que un determinado reo cumpla la totalidad de las penas impuestas, a la vista de sus circunstancias personales — resocialización efectiva, inserción sociolaboral—o de consideraciones de carácter humanitario —enfermedad, dependencia, familia a su cargo...). Normalmente, cada indulto requerirá el criterio favorable bien del ministerio fiscal bien del propio tribunal enjuiciador, además de la audiencia previa a la persona ofendida.

Aclarado esto, a la luz de la experiencia más reciente, de sus patologías, y los debates más recientes, ahora parece indiscutible — hay ya jurisprudencia incluso (Sala III del Tribunal Supremo) - la necesidad de explicar la motivación fundante de cada decisión y de cada Real Decreto de concesión de la «gracia». Y la urgente conveniencia de articular legalmente su respectivo control judicial (en sede 
contencioso administrativa y, solo en su caso, penal). Procede exigir asimismo, al inicio de cada legislatura, la publicación por el Gobierno de las «directrices generales» de la «política de indultos»: esto es, la concreción de los criterios generales de admisibilidad y de exclusión (en función de los informes preceptivos, señalando cuáles han sido favorables y cuáles desfavorables).

$Y$, por supuesto, urge adoptar una nueva ley de indultos, postconstitucional y plenamente conformada a la Constitución y a la jurisprudencia del TC y del TS. Una ley acordada, con mayoría amplia (aun cuando la ley no sea orgánica), y plenamente consistente con la conciencia democrática y experiencia acumulada en estos años. Una ley que explicite aquellos supuestos en que nunca podrá concederse la «gracia», debiendo incluirse, entre otros, los de corrupción de cargos públicos (singularmente en los supuestos de enriquecimiento ilícito en el ejercicio del cargo).

\section{PABLO LUCAS MURILLO DE LA CUEVA}

5.1. El indulto particular es una institución que permanece en los ordenamientos democráticos. Nuestra Constitución lo recoge en el precepto citado en la pregunta y vuelve a mencionarlo en el artículo 102.3 para calificarlo como prerrogativa real de gracia y excluir su aplicación en los supuestos de responsabilidad criminal de los miembros del Gobierno. La regulación legal vigente del indulto es, como también se dice en la pregunta, la establecida en la Ley de 18 de junio de 1870 con las modificaciones que introdujo en ella la Ley 1/1988, de 14 de enero.

Como es natural, la regulación legal del indulto solamente puede ser entendida y aplicada de acuerdo con el conjunto de las disposiciones constitucionales. Desde luego, la forma en que el constituyente se ha ocupado de él no lo ha facilitado. No me refiero tanto a que lo incluya entre las funciones del Rey cuanto a que lo califique como prerrogativa real de gracia. El uso por el constituyente de esta denominación ha dado pie a interpretaciones que han tratado de explicar el indulto como una decisión, no sólo formal, del Jefe del Estado y, en consecuencia, protegida por su estatuto de inviolabilidad e irresponsabilidad.

No me parece necesario insistir en que tal entendimiento no encaja ni en la configuración constitucional de la Corona, ni en el marco del Estado social y democrático de Derecho en que España está constituida. El indulto, en tanto supone el perdón de toda o de parte de la pena a la que un tribunal de justicia, tras el correspondiente proceso con todas las garantías, ha condenado a quien ha considerado culpable de uno o varios delitos, incide no sólo en la ejecución de una sentencia firme sino también en el derecho a la tutela judicial de las víctimas del delito y en el más amplio interés de la sociedad en el cumplimiento de las penas. Supone, pues, una solución excepcional frente a reglas y principios esenciales. De ahí que su regulación deba asegurar que solamente se concede cuando median las 
circunstancias singulares, previstas por el legislador, que justifican esa excepción. Para ello ha de establecer un procedimiento que permita contrastar que se dan efectivamente

Se trata, pues, la del indulto de una decisión revestida de complejidad para cuya adopción por el Gobierno el legislador decimonónico — que, recordémoslo, es el surgido de la revolución democrática de septiembre de 1868- quiso, con buen criterio plasmado en la Ley de 18 de junio de 1870, que tuviera a la vista el parecer del tribunal sentenciador, el informe del centro penitenciario de cumplimiento y el criterio del Ministerio Fiscal así como el de la parte agraviada. También exigía la Ley de 1870 que el acuerdo del Consejo de Ministros que concediera el indulto fuera motivado.

La modificación efectuada por la Ley 1/1988, suprimió del artículo 30 la exigencia expresa — que sí figuraba en el texto original — de que el Real Decreto de concesión del indulto sea motivado. Este cambio legal reforzó los argumentos de quienes entienden la decisión de indultar como un acto libre del Gobierno inmune al control judicial salvo en los aspectos estrictamente formales. No obstante, la jurisprudencia ha terminado por superar aquellas interpretaciones de la Ley de 1870 que, tras su modificación de 1988, sostenían que el Gobierno, el Consejo de Ministros, en quien reside la facultad sustancial de conceder o no el indulto, ni debe motivar su decisión ni está sujeto al adoptarla al límite de la interdicción de la arbitrariedad que impone el artículo 9.3 de la Constitución.

A este respecto, son importantes dos sentencias del pleno de la Sala Tercera del Tribunal Supremo. La primera [sentencia de 2 de diciembre de 2005 (recurso 161/2004)] se ocupó de la cuestión de si la resolución de los expedientes de indulto entraba o no en las facultades de ordinaria administración a que se contraen las que puede ejercer el Gobierno en funciones. Respondió afirmativamente a esa pregunta pero lo relevante ahora es que avanzó una interpretación del régimen del indulto que, de un lado, señaló que su concesión o denegación corresponde al Gobierno y que el Jefe del Estado, aunque expida el Real Decreto correspondiente, no interviene en la adopción de esa decisión. Luego, apoyándose en la exposición de motivos de la Ley de 1870, insistía en la necesidad de la motivación que debía ofrecer el Consejo de Ministros. La segunda [sentencia de 20 de noviembre de 2013 (recurso 13/2013)] afrontó directamente la configuración constitucional del indulto en el Estado social y democrático de Derecho.

De ella importa recordar ahora que destacó el carácter excepcional del indulto y que la decisión que el Gobierno debe tomar al respecto supone un acto discrecional aunque no posee la naturaleza de acto administrativo. Y que, si bien por esta razón no le es exigible una motivación en sentido técnico, sí deben desprenderse del Real Decreto que lo conceda las razones de justicia, equidad o utilidad pública en que se apoya. Y que, si bien el control jurisdiccional no puede extenderse al núcleo esencial de la decisión de indultar o no, sí se extiende a la comprobación de si ha mediado o no arbitrariedad. Así, pues, aunque esa fiscalización sea meramente externa, versa sobre la comprobación de si la decisión de indultar 
cuenta o no con soporte fáctico suficiente que permita establecer si, al adoptarla, hubo o no error material patente, arbitrariedad o manifiesta irrazonabilidad lógica. Comprobación que ha de hacerse en el expediente y en el propio Real Decreto.

5.2. A fin de evitar nuevas controversias, me parece conveniente elaborar una ley reguladora del indulto que despeje definitivamente toda duda sobre la necesidad de que el Consejo de Ministros motive sus decisiones, sobre todo cuando se aparte del parecer del tribunal sentenciador o del Ministerio Fiscal o del sentido de los informes del centro de cumplimiento.

Por otra parte, no se debe olvidar que el Código Penal (artículo 4.3) obliga al juez o al tribunal, sin perjuicio de ejecutar la sentencia, a acudir al Gobierno exponiendo lo conveniente sobre la concesión de indulto «cuando de la rigurosa aplicación de las disposiciones de la Ley resulte penada una acción u omisión» que a su juicio «no debiera serlo, o cuando la pena sea notablemente excesiva, atendidos el mal causado por la infracción y las circunstancias personales del reo».

Es decir, el indulto es contemplado por el legislador penal como una válvula de escape para remediar los que no son sino defectos graves del sistema punitivo. Conviene no pasarlo por alto porque buena parte de los indultos que se conceden se inscriben en este marco, o sea forman parte de la que se podría llamar aplicación normal del ordenamiento penal. Se trata de una normalidad patológica pues se ha de suponer que contiene los mecanismos necesarios para que a cada delito corresponde una pena proporcionada.

Así, pues, la preocupación por impedir que el Gobierno haga un uso arbitrario de la potestad de indulto no debe llegar al extremo de impedir o dificultar el funcionamiento de esa válvula correctora del exceso punitivo al que puede conducir la aplicación de las leyes penales.

\section{ANGEL RODRÍGUEZ-DÍAZ VERGARA}

Me parece evidente que cuando un tema de tanta trascendencia como los indultos sigue estando regulado por una Ley de finales del siglo XIX es porque no se han acometido reformas normativas que, como mínimo, lo deberían haber adaptado a la realidad actual.

En línea de principio, no creo que el art. 62.i) CE, que es, efectivamente, la única mención al derecho de gracia en la Constitución, se pueda esgrimir como argumento suficiente para fundamentar la inconstitucionalidad de su eliminación. La naturaleza de esa disposición constitucional no implica, creo, «reconocer» el derecho de gracia, sino que se agota en la atribución al Jefe del Estado de su ejercicio (siempre, claro está, dentro de las notas de actos reglados y refrendados que caracterizan todas las funciones del Rey). Esa atribución («corresponde al Rey») no bastaría para decretar la inconstitucionalidad de la eventual supresión de los indultos. Es decir, lo que del art. 62,i) puede deducirse, en mi opinión, es sólo que no sería posible sin la correspondiente reforma constitucional desapode- 
rar al Rey de sus funciones relacionadas con el derecho de gracia, pero no que deba mediar una reforma constitucional para erradicar este último, del mismo modo que, por ejemplo, una eventual reforma legislativa que suprimiera las Reales Academias no podría verse impedida por el hecho de que la Constitución atribuya al Rey su alto patronazgo. Lo que quiero decir, en definitiva, es que la atribución de funciones regias a este respecto no basta para afirmar que el derecho de gracia se encuentra, como tal, constitucionalizado en nuestra Norma Suprema.

Que el indulto sea, siempre en mi opinión, totalmente disponible para el legislador no significa, va de suyo, que su desaparición deba considerarse conveniente. Por el contrario, debería mantenerse sin desnaturalizarlo, es decir, mantenerse para servir en exclusiva para la finalidad para la que está pensado: ser un instrumento para alcanzar la justicia material cuando el ordenamiento no deje ninguna otra posibilidad para conseguir ese objetivo.

A mi juicio, el riesgo de desnaturalización del indulto se incrementa en la medida en que se acentúa el ámbito de la discrecionalidad gubernamental en su aplicación, bien por la no exigencia de motivación (y en este sentido es criticable la reforma de la Ley 1/1988) bien por un menor protagonismo de los propios tribunales sentenciadores, que deberían tener capacidad decisiva para decretarlo o, al menos, para impedirlo.

No creo, sin embargo, que sea compatible con la naturaleza del indulto prohibir su aplicación a determinados delitos. Como toda cláusula de cierre, está prevista para casos a los que el sistema no puede dar respuesta por los cauces ordinarios, por lo que establecer a priori que una determinada categoría de delitos (por ejemplo, los de corrupción) no son susceptibles de indulto, implicaría desconocer que, precisamente, su carácter excepcional desaconseja este tipo de exclusiones generales.

6. ¿En el terreno de las prácticas y de los usos de nuestro Estado de Derecho podemos entender que el Ministerio Fiscal tiene suficientemente asegurado el ejercer sus funciones conforme a los principios consagrados en el art. 124 CE de «legalidade imparcialidad»?

\section{RAFAEL BUSTOS GISBERT}

«La convención es la carne que rodea el seco hueso de la norma» decía sir Ivor Jennings y, ciertamente, España no se caracteriza por la existencia de convenciones que den forma, contenido y seguridad al funcionamiento de las instituciones. Creo que esta afirmación es particularmente cierta respecto al Ministerio Fiscal. En el terreno de las prácticas y usos españoles respecto al funcionamiento del Ministerio Fiscal creo que tales prácticas han dependido excesivamente de la personalidad y convicciones del Fiscal General del Estado. Y en tal sentido la inde- 
pendencia con la que se han movido los fiscales ha dependido del grado de intervencionismo con el que el Fiscal General ha ejercido sus funciones lo que, a su vez, dependía de las convicciones de quien ocupaba el puesto. Obviamente esta no es una buena solución y resulta desalentador comprobar cómo los Fiscales Generales más respetuosos con la independencia en la actuación de los miembros de la carrera fiscal, habitualmente, han abandonado sus cargos antes de tiempo y han sido sustituidos por personas más intervencionistas.

Pese a todo, creo que no debería generalizarse la afirmación de que los fiscales en España no son imparciales en el ejercicio de sus funciones. En la inmensa mayoría de los casos tengo la convicción de que actúan con absoluta imparcialidad. No debe olvidarse nunca que los fiscales no son independientes, ni probablemente tampoco tengan por qué serlo. El Ministerio Fiscal es el «brazo judicial» del Ejecutivo y un instrumento básico de éste para orientar la política criminal del Estado en un sentido u otro estableciendo las prioridades en el campo de la persecución y represión del delito, así como en la defensa del interés público..

El único problema real respecto a la imparcialidad del Ministerio Público se encuentra, a mi juicio, en los casos en los que el gobierno tiene o puede tener algún tipo de interés político directo y muy singularmente en los casos de corrupción política que le puedan afectar tanto al partido mayoritario como a los que puedan competir con él. En este punto es donde una reforma permanente, acordada entre los partidos es verdaderamente necesaria, blindando totalmente la fiscalía anticorrupción como fiscalía especializada, dotada con los suficientes medios materiales y personales y con una jerarquía claramente separada del gobierno de turno y del propio Fiscal General. Creo que con eso bastaría para suplir los problemas que, a día de hoy, puedan aquejar al Ministerio Fiscal en España.

Ahora bien, si finalmente se atribuyera la instrucción penal al Ministerio Fiscal es posible que las modificaciones tuvieran que ser de un mayor calado.

\section{JUAN FERNANDO LÓPEZ AGUILAR}

Aunque en principio la respuesta pueda seguir siendo «sí», ninguna institución escapa ya a la discusión ni al debate. Tampoco, por descontado, el ministerio fiscal.

Procede reforzar los órganos colegiados del ministerio fiscal (Consejo Fiscal y Junta de Fiscales, arts. 14 y 27 del EOMF, Ley 50/81, de 30 de diciembre, varias veces reformada). Se trata de órganos cuya función es moderar el principio de jerarquía (su «dependencia jerárquica», en cuya cúspide se sitúa el Fiscal General del Estado, sobre el que conviene reforzar su inamovilidad durante su mandato, en la dirección apuntada por la reforma del EOMF adoptada en 2007), interponiendo controles que sirvan a asegurar la «unidad de actuación».

Porque precisamente esa unidad de actuación sigue siendo crucial para favorecer los valores constitucionales de la igualdad ante la ley (especialmente ante la 
ley penal, arts. 9.2 y $14 \mathrm{CE}$ ) y la seguridad jurídica frente a la interdicción de la arbitrariedad (art. 9.3 CE). Y la publicidad de las deliberaciones, motivaciones y conclusiones de cada directriz (dictámenes, resoluciones e informes) orientadora de la acción del ministerio fiscal en cada caso concreto.

Dicho eso, he desarrollado en otros escritos (La Justicia y sus problemas en la Constitución, Tecnos, Temas Clave, 1996) mi lectura doctrinal de los principios constitucionales de «legalidad e imparcialidad». La «dependencia jerárquica» y la «unidad de actuación» tienen dimensiones preferentemente organizativas, mientras que la «legalidad»e «imparcialidad» se proyectan en el plano funcional. La «imparcialidad» se configura — a diferencia de la «independencia» judicial, puesto que la «dependencia jerárquica» no es asimilable sin más a la «independencia», en cierto modo antitética - como una posición de «parte» en interés de ley, «parte imparcial» si se quiere (o tercero «metapartes» donde ya exista acusación, puesto que la de tercero «suprapartes» corresponde al Juez que enjuicia), cuya función consiste en la promoción del «interés público protegido por la ley» por «medio de órganos propios». Tal como se desprende de la lectura sistemática del art. $124 \mathrm{CE}$ y su desarrollo legal en el EOMF y en las leyes procesales en los diferentes órdenes de la jurisdicción, y de modo singular en los procedimientos penales y de protección de menores.

\section{PABLO LUCAS MURILLO DE LA CUEVA}

6.1. La reforma del Estatuto Orgánico del Ministerio Fiscal efectuada por la Ley 24/2007, de 9 de octubre, ha dotado al Fiscal General del Estado de una posición de sustancial estabilidad en el cargo.

En efecto, su artículo 31 fija la duración de su mandato en cuatro años y solamente permite que cese antes de su transcurso si concurre alguna de las causas tasadas que enumera. Son estas: (i) la petición propia;(ii) incurrir en alguna de las incompatibilidades o prohibiciones previstas en el propio Estatuto Orgánico; (iii) incapacitarse o enfermar de manera que le inhabilite para el ejercicio del cargo; (iv) el incumplimiento grave o reiterado de sus funciones; (v) y el cese del Gobierno que le nombró.

Aunque es el Consejo de Ministros el que aprecia la concurrencia de esas circunstancias, su margen de decisión es escaso o nulo. La existencia de incompatibilidades o prohibiciones tendrá que ser acreditada y contrastada con referencia al precepto estatutario que la establezca. La enfermedad o incapacidad deberá comprobarse médicamente. El cese del Gobierno que lo nombró es un hecho notorio y la renuncia del Fiscal General del Estado es una decisión que solamente le concierne a la persona que desempeñe el cargo.

Es verdad que la causa consistente en el incumplimiento de sus funciones conlleva elementos de indeterminación que no se dan en las otras. Sin embargo, no basta con cualquier incumplimiento sino que el que se quiera hacer valer para 
destituirle anticipadamente ha de ser grave o reiterado. Es decir, el Consejo de Ministros que decida cesarle por este motivo habrá de identificar, primero, la función o funciones incumplidas y, después, la gravedad o reiteración del incumplimiento. Incumplimiento, función, gravedad y reiteración — como, por cierto, incompatibilidad, prohibición o incapacidad o enfermedad inhabilitante- son conceptos judicialmente asequibles y, por tanto, su concurrencia según jurisprudencia consolidada, es controlable por la Sala Tercera del Tribunal Supremo, que es la competente para conocer de los recursos que se interpongan contra los actos del Consejo de Ministros.

Esta circunstancia es un factor que, sin duda, frenará eventuales propósitos de cese anticipado del Fiscal General del Estado sin que realmente se de ese supuesto de incumplimiento o sin que se de alguna de las otras circunstancias tasadas legalmente previstas.

La garantía de estabilidad que supone este régimen jurídico es el presupuesto para que el Fiscal General del Estado desempeñe conforme su leal criterio el cargo que, de acuerdo con el artículo 22.2 del Estatuto Orgánico, supone la jefatura del Ministerio Fiscal, su representación en toda España, la facultad de impartir órdenes e instrucciones convenientes al servicio y al orden interno de la institución y, en general, la dirección e inspección del Ministerio Fiscal, todo ello para el cumplimiento de las funciones que le encomienda el artículo 124.1 de la Constitución.

6.2. El Ministerio Fiscal del que el Fiscal General del Estado es el superior jerárquico, debe actuar, según el apartado 2 del artículo recién citado y recuerda la pregunta, con sujeción a los principios de legalidad e imparcialidad. Se trata de unos vínculos de los que no puede desprenderse.

Por otro lado, es clara la voluntad del legislador de relacionar el cargo de Fiscal General del Estado con el Gobierno que le nombra y, en último término, con la legislatura, pues no otra cosa significa el límite de los cuatro años de mandato y la regla de la prohibición de su renovación salvo que haya permanecido en el cargo menos de dos años (artículo 31.2 del Estatuto Orgánico). Esa relación no es casual pues la dirección del Ministerio Fiscal no ha de ser ajena a la orientación política que trace el Gobierno, pues éste, según el artículo 8 del Estatuto Orgánico, puede interesar, precisamente, del Fiscal General del Estado que promueva ante los tribunales de justicia las actuaciones pertinentes en orden a la defensa del interés público.

Es decir, la Ley ofrece un cauce para que el Gobierno transmita al Fiscal General del Estado sus criterios de política criminal, que serán normalmente observados por el Ministerio Fiscal en su conjunto. Ahora bien, como el Fiscal General del Estado no es un subordinado, no depende jerárquicamente del Gobierno y la Constitución confiere al Ministerio Fiscal una posición caracterizada por su imparcialidad y su sometimiento el principio de legalidad, el legislador — que reconoce su «autonomía funcional dentro del Poder Judicial» (artículo 2.1 del Estatuto Orgánico) — se ha tenido que limitar a facultar al Gobierno para «intere- 
sar» del Fiscal General del Estado determinadas actuaciones. No está, pues, legalmente obligado a emprenderlas y si, como hemos visto, no puede ser cesado libremente, tampoco dispone el Gobierno de la posibilidad de removerlo. En consecuencia, si se diera el caso de que considerara improcedente la adopción de alguna o algunas iniciativas interesadas por el Gobierno, queda a su decisión no adoptarlas sin que eso implique ningún tipo de responsabilidad para él ni, desde luego, pueda ser considerado, en principio, incumplimiento de sus funciones.

Puede suceder, por tanto, que entre el Fiscal General del Estado y el Gobierno y, en particular, el Ministerio de Justicia, que es con el que debe comunicarse (artículo 8.2 del Estatuto Orgánico), surjan diferencias de criterio sobre extremos considerados importantes para ambas partes. Esta hipótesis puede traducirse en dificultades en la actuación del Ministerio Fiscal en la medida en que, al fin y al cabo, fue nombrado por el Gobierno. Además, hay supuestos, como los disciplinarios, en que las decisiones del Fiscal General del Estado son recurribles en alzada ante el Ministerio de Justicia y en tanto, es este último el llamado a proveer al Ministerio Público de los medios que precisa para su funcionamiento e, incluso a adoptar por sí mismo o a llevar al Consejo de Ministros la adopción de normas reglamentarias sobre el propio Ministerio Fiscal, son perfectamente imaginables las hipótesis conflictivas posibles.

Esa circunstancia y el deseo de no causar perjuicios a los intereses públicos pueden explicar que el Fiscal General del Estado, cuyo cese libre no está al alcance del Gobierno, sin embargo prefiera renunciar al cargo a mantener una situación de enfrentamiento.

6.3. No se debe pasar por alto, además, que el Fiscal General del Estado debe oír antes de adoptar sus principales decisiones a la Junta de Fiscales de Sala. Esta es un órgano que le asiste en materia doctrinal y técnica (artículo 15 del Estatuto Orgánico) y que debe ser oído, entre otros asuntos, sobre la viabilidad o procedencia de las actuaciones interesadas por el Gobierno, sobre aquellas actuaciones que afecten al Gobierno o a alguno de sus miembros o sobre los supuestos en que se deba mantener la unidad de criterio o un fiscal considere contraria a las leyes o improcedente por cualquier motivo una orden del propio Fiscal General del Estado (artículos 8.2, 24.225 y 27.1 del Estatuto Orgánico).

Aunque el Fiscal General del Estado sea el superior jerárquico del Ministerio Público, no podrá desconocer el criterio de la Junta de Fiscales de Sala. Y, de ser contrario al suyo, se verá obligado a razonar, si decide mantenerlo, por qué se separa del parecer de ese órgano. En cambio, cuando coincida, es claro que verá fortalecida su posición.

6.4. En definitiva, si bien la atribución al Gobierno de la facultad de nombrar al Fiscal General del Estado — ciertamente, oyendo previamente al Consejo General del Poder Judicial, que solamente en un caso hizo observaciones críticas, absolutamente ignoradas por el Consejo de Ministros y, tras comparecer el propuesto ante la comisión correspondiente del Congreso de los Diputados (artículos 124 de la Constitución y 29.2 del Estatuto Orgánico)— permite suponer que 
elegirá a quien sintonice con sus orientaciones políticas y que, por tanto, las trasladará a la actuación del Ministerio Público en la medida que sea posible, institucionalmente el Estatuto Orgánico le concede suficiente autonomía al Fiscal General del Estado para desplegar su propio criterio.

\section{ANGEL RODRÍGUEZ-DÍAZ VERGARA}

Si, en el caso del poder judicial, el problema actual es que la falta de independencia del conjunto puede llegar a afectar a la imparcialidad del juez (véase la respuesta a la pregunta tercera), en relación con el Ministerio Fiscal, la imparcialidad de éste debe constitucionalmente convivir con un diseño constitucional distinto, donde el principio aplicable es el de jerarquía y no el de independencia. En mi opinión, el diseño constitucional «imparcialidad más jerarquía» debería mantenerse, incluso si en el futuro se encomienda a los fiscales la instrucción de los procesos penales.

7. ¿Desea usted hacer alguna otra sugerencia sobre cómo asegurar en nuestro Estado de Derecho la vigencia práctica de la independencia de los órganos de nuestra Administración de Justicia?

\section{RAFAEL BUSTOS GISBERT}

Creo que convendría distinguir dos ámbitos en los que actuar. El primero sería una reforma legal y el otro una reforma constitucional.

Desde un punto de vista legal creo que se podría mejorar mucho la independencia judicial si se facilitara su mayor capacitación y que ésta fuera tenida en cuenta de manera determinante en los criterios de selección inicial y de promoción posterior. El sistema de selección debería ser reformado manteniendo la objetividad alcanzada con el concurso oposición, pero complementada con un periodo de formación inicial más largo que fuera verdaderamente selectivo y vinculado a estancias largas en los juzgados y tribunales. Un «MIR» para jueces y fiscales resultaría, creo, un buen sistema de asegurar que las personas encargadas de aplicar el Derecho no sólo lo conocen, sino que además reúnen las condiciones necesarias para hacerlo de manera correcta e independiente. Pero para ello habría que cambiar muchos otros aspectos en la organización de otras profesiones si queremos que aquellos que no superen una formación de este tipo no puedan acceder a otras profesiones (como podrían ser letrados de la Administración de Justicia u otros puestos de especialización jurídica en la administración no necesariamente vinculados con el poder judicial o el ejercicio de la función jurisdiccional). Otro tanto cabría decir de la formación continua que debería cobrar cada 
vez más importancia en un mundo jurídicamente tan cambiante como el que vivimos. Ofrecer itinerarios de formación especializada, tener en cuenta la superación de cursos y evaluaciones de especialidades para la promoción en la carrera podría añadir criterios objetivos para la promoción de magistrados a instancias superiores.

Si lo que nos planteáramos fuera una reforma constitucional me preguntaría si sigue siendo necesaria la propia existencia del CGPJ o del Fiscal General del Estado.

Respecto al CGPJ es obvio que en regímenes en transición es necesario como lo era en España. No sé si ahora es tan necesario y si no sería más adecuado transferir sus funciones a los propios órganos jurisdiccionales las relativas a régimen disciplinario y promoción interna (esta a una Sala de gobierno del TS para los cargos superiores como magistrado TSJ, AN y TS - a la que también podría corresponder las de propuesta para el TC) repartiendo las restantes en órganos mixtos jueces-gobierno (selección, formación, relaciones internacionales) o eliminándolas (informe). Pero no creo que sea viable en la medida en que posiblemente podría verse como eliminación de un órgano importante. Si no puede eliminarse quizás regular su funcionamiento tomando como punto de referencia que si es un órgano de gobierno no puede ser tan numeroso como 21 miembros y quizás 7 serían suficientes....

Respecto al Fiscal General del Estado posiblemente lo haría desaparecer y dejaría al ministro de Justicia formalmente como Fiscal General del Estado con capacidad para dar instrucciones generales y establecer las directrices generales de actuación, pero sin capacidad real para dar instrucciones concretas. El consejo fiscal así como la estructura descentralizada de la fiscalía podría asumir el resto de funciones. En cuanto a nombramientos solo los más importantes los haría el Ministro de Justicia a partir de ternas propuestas por el consejo fiscal.

\section{JUAN FERNANDO LÓPEZ AGUILAR}

No estaría mal incidir, entre otras medidas al alcance de la imaginación sustentada en la experiencia, en la planificación y ejecución de campañas de formación y de comunicación (educación, pedagogía y capacitación especializadas en estos campos) acerca de la recta comprensión y manejo de garantías instrumentales de la independencia judicial en nuestro ordenamiento, y su diferenciación respecto de otras variables que inciden en la concreta vertiente prestacional (medios personales, materiales, tecnológicos, presupuestarios y financieros) de la Administración de Justicia. Porque una y otra cosa son cosas que han de distinguirse, aunque a menudo se las confunda al servicio de intereses (corporativos, entre otros).

Especialmente relevante me parece distinguir la independencia judicial (razonablemente asegurada en España) de la crítica al actual cuadro de disfunciones 
operativas obedientes a la diversidad y heterogeneidad de líneas de «dependencia» político-administrativa que caracteriza el deficiente modelo constitucional que ha sido desarrollado en España a partir de lo dispuesto en los Títulos VI ( «Del Poder Judicial», arts. 117 a 127 CE) y VIII («De la Organización Territorial del Estado», arts. 137 a $158 \mathrm{CE}$ ) de nuestra Constitución.

No sólo porque estos dos Títulos resultan precisamente los de más defectuosa configuración, y por ello más urgidos de reforma según lo previsto en el Título X (arts. 166 a $169 \mathrm{CE}$ ). Sino también, y sobre todo, porque el actual esquema de distribución de competencias legislativas y ejecutivas en el campo de la Administración de Justicia resulta, por su dispersión y contradictoria manejo, de difícil comprensión incluso para sus actores (para sus operadores y sus protagonistas), no digamos ya para el conjunto de la ciudadanía (esto es, los justiciables, los ciudadanos prestatarios de esa particularmente espesa, a ratos irracional, articulación constitucional, estatutaria y legal de la acepción prestacional del servicio público judicial). Piénsese, para expresarlo, en la «dependencia» del juez (LOPJ y CGPJ), del ministerio fiscal (EOMF y Consejo Fiscal), de los Secretarios de Justicia (ahora llamados «letrados», Ministerio de Justicia y CC.AA), y funcionarios de Justicia (Ministerio de Justicia y CC.AA, según concretas competencias y traspasos efectivos); además de, por su lado, abogados (Consejo General y Colegios profesionales) y procuradores (Colegios nacional y territoriales), sobre los que también dispersan competencias asimétricas el Ministerio de Justicia y las CC.AA.

Sostengo también desde hace tiempo que la independencia judicial padece actualmente amenazas que no provienen de la estructura formal de poderes constituidos: poderes fácticos, económicos, financieros, mediáticos, tejen bien de consuno o bien a discreción sus mallas tentaculares de incentivos positivos y negativos sobre los jueces en los actos de su jurisdicción, con la intención de condicionar su acción y sus resoluciones.

Insisto aquí en lo ya apuntado con anterioridad. En este concreto orden de consideraciones, el impacto de los poderes mediáticos es singularmente temible: si la adulación hace mella en la conducta del juez, la construcción de perfiles «heroicos» $\mathrm{o}$ «magnificados» del juez al servicio de un interés (transparente, aunque no explícito), su alternancia con la «deconstrucción» y/o la «demolición» de su personalidad (currículum, trayectoria, prestigio profesional y credibilidad personal....) resulta demoledora para la independencia del titular responsable del órgano judicial que entiende de casos «sensibles» por su interés para los medios, y a la vista, claro está, de los concretos intereses económicos, financieros y políticos a los que sirvan esos medios de comunicación y sus concretas estructuras accionariales y de propiedad.

Huelga aclarar, por descontado, que la «independencia» de los medios (y de sus informadores y opinadores, claro) no resiste, en este ámbito, y en el actual contexto económico y social, ningún test de calidad remotamente comparable al que se espera de los jueces. 


\section{PABLO LUCAS MURILLO DE LA CUEVA}

Además, de avanzar en la consecución de una convención constitucional que, por fin, neutralice políticamente la formación de los órganos constitucionales de garantía como el Tribunal Constitucional y el Consejo General del Poder Judicial $\mathrm{y}$, en general, en una cultura de respeto institucional, hay aspectos menos llamativos políticamente pero muy importantes que suelen pasarse por alto.

En efecto, la actuación de los jueces precisa de medios personales y materiales para que alcance los fines que la Constitución le asigna pero los jueces españoles carecen de toda capacidad de decisión sobre las dotaciones con las que cuentan. Es radicalmente verdad en nuestro caso lo que Alexander Hamilton (The Federalist n. ${ }^{\circ} 78,14$ de junio de 1788) decía al presentar al Judicial como el poder menos peligroso (the least dangerous branch) pues no dispone de la fuerza ni del dinero y depende del Ejecutivo para hacer que se cumplan sus sentencias.

Los jueces españoles, efectivamente, no disponen de capacidad de decisión sobre los medios personales y materiales a su disposición. Las competencias se distribuyen entre el Ministerio de Justicia (las dos Castillas, Extremadura, Murcia, y Baleares, además de Ceuta y Melilla) y las doce Comunidades Autónomas que han asumido competencias en la materia, además de, en menor medida, la Administración Local.

Los jueces, pues, pueden pedir y lo hacen constantemente pero las necesidades de personal y material las atienden o no esas Administraciones competentes.

La realidad es que, al día de hoy, a pesar de que se han hecho esfuerzos apreciables y están en curso medidas importantes de mejora, nuestros juzgados y tribunales no disponen ni del personal cualificado suficiente, ni de las infraestructuras e instrumentos técnicos precisos para cumplir eficientemente su cometido.

Incluso, en número de jueces por habitantes, España está lejos de la media europea. Los miembros de la carrera judicial son algo más de la mitad de los que deberían ser si quisiéramos situarnos en ese nivel [Boletín de Información Estadística. Consejo General del Poder Judicial, n. ${ }^{\circ} 37$, diciembre de 2014\}. Y esa diferencia es otro factor que, unido a los anteriores, se traduce en sobrecarga de trabajo y disfunciones que podrían ser evitadas si se dispusiera de una planta judicial ajustada a las necesidades de la sociedad española de nuestros días y de una Administración de Justicia bien equipada.

Los verdaderos retos pendientes del Poder Judicial en España están en este plano más prosaico y afrontarlos supone, además de la consciencia de ellos, el firme propósito de dedicar importantes recursos públicos a colmar las insuficiencias existentes y de realizar una actuación coordinada entre las Administraciones competentes para que las soluciones converjan en toda España en los mismos medios y sistemas. 


\section{ANGEL RODRÍGUEZ-DÍAZ VERGARA}

A mi juicio, la independencia de la Administración de Justicia no se vería precisamente favorecida si se acometieran las reformas encaminadas a instaurar efectivamente los Consejos de Justicia autonómicos contemplados en algunos Estatutos de Autonomía reformados a partir del año 2006. Una cosa es que estos órganos no puedan reputarse inconstitucionales siempre que se entienden dentro de los límites establecidos por la STC 31/2010, que declaró inconstitucional determinados preceptos de la reforma del Estatuto de Autonomía de Cataluña llevada a cabo por la LO 6/2006, y otra muy distinta aplaudir la decisión tomada por algunos EEAA, de descentralizar el gobierno del Poder judicial, extendiendo a las CCAA un modelo cuyas imperfecciones ya se han puesto de manifiesto.

$$
* * *
$$

TITLE: Academic survey about the independence of the Judicial Power

ABSTRACT: In this academic survey a group of Constitutional Law Professors answer some questions about the independence of the Judicial Power and the Rule of Law and about the threats to this independence; the questions approach topics relative to the Judicial Power government, the procedural privileges, the regime of the Attorney General's office and judicial pardon or grant of clemency.

RESUMEN: En esta encuesta un grupo de Catedráticos de Derecho Constitucional contestan un conjunto de preguntas sobre la independencia del Poder Judicial en el Estado de Derecho, relativas a las amenazas que existen a esa independencia; las preguntas abordan temas relativos al Consejo General del Poder Judicial, la figura del aforamiento, el régimen del Ministerio Fiscal y el derecho de gracia, entre otros.

KEY WORDS: Independence of the Judicial Power, Rule of Law, Judicial Power government, Attorney General's office, judicial pardon or grant of clemency.

Palabras Clave: Independencia del Poder Judicial, Estado de Derecho, Consejo General del Poder Judicial, aforamiento, Ministerio Fiscal, derecho de gracia. 